\title{
Upholding God's Essence: Ibn Taymiyya on the Createdness of the Spirit
}

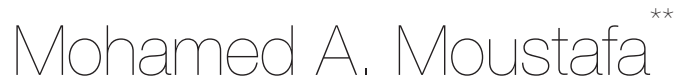

\begin{abstract}
Although scholarly attention has been paid to Ibn al-Qayyim's popular Kitäb al-rūh, the soulrelated views of his master are still ignored. Hence, this paper traces some of these ideas in Ibn Taymiyya's Khalq al-rüh, in which he asserts the soul's origination rather than its eternity, so as to uphold the idea of God's essence. This paper consists of two parts. Part I problematizes Khalq in light of previous research, presents the sources of the study, and addresses some concepts that are significant for appreciating the development of its main argument. The five major arguments that Ibn Taymiyya invokes to justify his viewpoint shall be reconstructed from Khalq. Likewise, some of the ambiguities surrounding his identification of those who hold opposite views shall be resolved. Part II provides an annotated translation of Khalq.
\end{abstract}

Keywords: Soul, spirit, eternity, origination, corporeality, Christology, antinomianism, eschatology, relation

* Work on this paper started during an MA Fulbright scholarship at Hartford Seminary, Connecticut (Jan 2013-Feb 2015). An earlier version was presented at the University of Geneva's international colloquium “The Body's Mind and the Mind's Body" (April 13, 2016). Thanks to the Nazariyat's reviewers for their comments, Yahya Michot for reading Khalq with me, as well as Frank Griffel, Steven Blackburn, Mahmoud Ayoub, Jon Hoover, and Tzvi Langermann for their notes.

** Assistant Lecturer, al-Azhar University, Faculty of Languages and Translation. Correspondence: m.moustafa@azhar.edu.eg 


\section{Introduction}

\section{Background}

I n 1932, D. B. Macdonald republished his comprehensive article on the soul. ${ }^{1}$ His student E. E. Calverley and I. R. Netton cite it extensively and recommend it in their encyclopedia entry on the same topic. ${ }^{2}$ Macdonald's interest in psychology might have inspired his doctoral student F. T. Cooke to study and translate, under his supervision, Ibn al-Qayyim's (d. 751/1350) Kitāb al-rūh, the most famous work on the soul in Arabic literature. ${ }^{3}$ In 1935, Cooke published an article to introduce Kitāb al-rūh, without referencing his previous work. ${ }^{4}$ Tzvi Langermann published two articles on this book: the first one shows Ibn al-Qayyim's appropriation of philosophical terms for Islamic usage, ${ }^{5}$ and the second one studies the book's structural development. ${ }^{6}$

Asserting that Kitāb al-rūh represents the standard work on the soul's psychology and eschatology for the majority of Muslims, Macdonald devotes more space in his article to it. He opines that Ibn al-Qayyim sticks to Hanbalī literalism, which venerates scriptural authority. Like Macdonald, Cooke avers that Ibn al-Qayyim fits the soul into a material scheme that defies al-Ghazāli's (d. 505/1111) dismissal of predicating the soul on spatial terms: "His materialistic system, acceptable to the vast majority of Muslims, has been instrumental in keeping Islām true to its genius for theological concretion."7

Although Ibn Taymiyya (d.728/1328) briefly features in Macdonald's and Cooke's articles as a fundamentalist Hanbalī, ${ }^{8}$ Langermann states that both Shaykh

1 Duncan B. Macdonald, "The Development of the Idea of Spirit in Islam I," The Muslim World 22.1 (January 1932): 25-42 [part II: 153-68, April 1932]; reprinted from idem, Acta Orientalia 9 (1931): 307-51.

2 See "Nasf" in The Encyclopædia of Islam, 2d ed. (Leiden: E. J. Brill, 1960-2004), 7:880-84 [hereinafter EI2].

3 Kitāb al-rūḥ has found its way to thrillers, such as Orhan Pamuk's My Name is Red. Birgit Krawietz calls it "a real best seller" in her "Ibn Qayyim al-Jawzìyah: His Life and Works," Mamlük Studies Review 10 (2006): 34. For the most recent and credible edition, see Ibn Qayyim al-Jawziyya, Kitāb al-rūhn, ed. Muhammad Ajmal al-Ișlāhịi, 2 vols. (Makkah: Dār 'Ālam al-Fawā’id, 1432/2011) [hereinafter Rūḥ].

4 Francis T. Cooke, “Ibn al-al-Qaiyim's Kitāb al-rūh,”, The Muslim World 25 (1935): 129-44 [hereinafter "Ibn al-Qaiyim"]. By his previous work, I mean "Ibn al-Qaiyim’s Kitāb al-Rūḥ: Translation with Introduction and Annotation" (PhD diss., Hartford Seminary Foundation, 1934).

5 Tzvi Langermann, "The Naturalization of Science in Ibn Qayyim Al-Ğawziyyah’s Kitāb al-rūḥ," Oriente Moderno, XC (2010): 201-18 [hereinafter "Naturalization"].

6 Tzvi Langermann, "Ibn al-Qayyim's Kitāb al-rūh: Some Literary Aspects," in Islamic Theology, Philosophy and Law: Debating Ibn Taymiyya and Ibn Qayyim al-Jawziyya, ed. Birgit Krawietz and Georges Tamer (Berlin: de Gruyter, 2012), 94-122 [hereinafter "Literary"].

7 Cooke, "Ibn al-Qaiyim," 131.

8 To some extent, this conclusion is true. In Khalq, Ibn Taymiyya draws on some Hanbali sources. Another study shows that he would even concur with "al-Ash 'arī's self-identification as a follower of Ibn Hanbal” 
al-Islām and his disciple are known to historians of sciences "on account of their thorough and robust refutations of so-called occult sciences, especially astrology." "Their motivations were more theological than philosophical or scientific." ${ }^{\prime}$ Furthermore, Langermann aptly speaks of Ibn al-Qayyim's twenty-first query in Kitāb al-rūh as largely being "an essay on morals." 10

While these works introduce Ibn al-Qayyim's Kitāb al-rūh, the germane and inspirational ideas of his intellectual master Ibn Taymiyya are ignored. Tracing some of these ideas, this paper provides an analytical introduction to as well as an annotated translation of a fatwa issued by Shaykh al-Islām Taqī al-Dīn Ahmad ibn Taymiyya, one that I call Khalq al-rūh (hereinafter Khalq). This text presents his position on the origination, eschatology, and corporeality of the soul. ${ }^{11}$

\section{Statement of the Problem}

In Khalq, Ibn Taymiyya argues for the soul's createdness rather than its eternity. I argue that he adopts this position to salvage and uphold the idea of God's essence vis-à-vis the human soul. He marshals diverse arguments that feature some proponents of his viewpoint, as well as categories of those who oppose it, whom he identifies in rather ambivalent terms. For him, believing in the soul's coeternity with God's essence has moral implications. Although Ibn Taymiyya manages to answer the questions he is asked in Khalq, his response poses certain problems. This paper is designed to address them.

The first problem is concerned with his methodology. For instance, he answers questions about a philosophical issue in a didactic religious language. This aspect of his work deserves an explanation. Also, he is ambivalent about his terminology. Despite the significance of the concept "God's essence" to his main argument, we

due to "doctrinal similarities." See Racha El Omari, “Ibn Taymiyya's 'Theology of the Sunna' and His Polemics with the Ash'arites," in Ibn Taymiyya and His Times, ed. Yossef Rapoport and Shahab Ahmed (Karachi: Oxford University Press, 2010), 104.

9 Langermann, "Naturalization," 203.

10 Langermann, "Literary," 141. This paper will pinpoint Ibn Taymiyya's concern with moral uprightness in Khalq.

11 The seventieth query in Ibn al-Qayyim's Kitāb al-rūh, 2:420-52, addresses the soul's eternity and origination. Ibn al-Qayyim essentially retains Ibn Taymiyya's structure and argument(s) and quotes verbatim from Khalq, MF, 4:217-20 (Rūh, 2:420-27). He also provides canonical and rational proofs on the soul's createdness (Rūh, 2:427-37), explains Q17:85 (Rūḥ, 2:437-51), and discusses the concept of relation (iḍāfa) (Rūh, 2:451-52). Except for occasional references in some footnotes, this paper does not attempt other comparisons of Khalq with Ibn al-Qayyim's seventieth query. 
are not told what this concept means in Khalq and, therefore, one needs to look elsewhere in his oeuvre for an explanation. Furthermore, while Ibn Taymiyya justifiably uses "spirit" interchangeably with "soul," he does not compare both concepts in Khalq; rather, he states that related discussions can be found in his other works.

The second problem concerns his referential authorities. We are informed, in fairly satisfying detail, of the scholarly positions he invokes in Khalq, which covers several pages of the fatwa. This is understandable, because he is asked to expound upon the opinions of "the People of the Sunna." ${ }^{12}$ However, he devotes one ambiguous paragraph to those who hold the opposite view. His reticence leaves us confused as to what he means by the first category (i.e., "the Sabian philosophers") and the other category (i.e., "the Sufis, Kalām theologians, and traditionists"), whom he describes as the "heretics of this community and its straying people." 13

As such, this introduction seeks to rationalize his overall argument in two steps: 1) Coming to terms with his methodology by identifying his epistemology and understanding of "God's essence" and "soul" as analytical concepts and 2) Reconstructing, via his referential backdrop in Khalq, the involved allied and opposing arguments from his other works. Only the second category, which he refers to ambivalently, will be discussed below. As this paper is primarily concerned with making sense of his opinions on the soul's origination in Khalq and related pieces, the topic is not discussed from the viewpoints of other scholars. ${ }^{14}$

\section{Primary Sources of the Study}

Given the nature of Khalq, this fatwa does not fully answer the questions that it poses. Hence, reference will be made to Ibn Taymiyya's other works to envision the background of his position. The analytical method used is partly inspired by the French theorist Gérard Genette's transtextuality, which comprises such categories as metatextuality (explicit and implicit textual references) and intertextuality (overt and covert quotations). ${ }^{15}$ Presented below is an inventory of Ibn Taymiyya's works that are cited in this paper. Works with an asterisk $\left(^{*}\right)$ before the short title

14 For representative case studies, see a collection of articles edited by Ayman Shihadeh, "The Ontology of the Soul in Medieval Arabic Thought," The Muslim World, 102.3-4 (2012): 413-616.

15 See, for example, S. A. Mirenayat and E. Soofastaei, "Gerard Genette and the Categorization of Textual Transcendence,” Mediterranean Journal of Social Sciences 6.5 (2015): 533-37. 
are cited more than once. For the two collections of FK and MF, the title of the section or treatise from which a citation is made will be mentioned before the short title. For non-Taymiyyan works, full bibliographical information is given the first time they are mentioned, and subsequently followed with short titles.

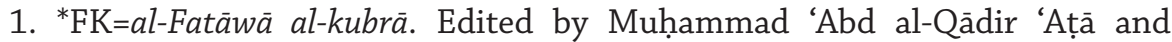
Mușțafā 'Abd al-Qādir 'Ațā. 6 vols. Beirut: Dār al-Kutub al-'Ilmiyya, 1408/1987.

a. Janā'iz=Kitāb al-janā’iz, FK, 5:359-68.

b. Ṭawā'if=Kitāb al-radd 'alā al-țawā'if, FK, 6:321-464.

2. Jawāb=al-Jawāb al-șaḥị̣ li-man baddala dīna al-Masīḥ. Edited by 'Alī b. Nāṣir, 'Abd al-'Azīz al-'Askar, and Hamdān al-Hamdān. 2d. ed. 7 vols. Riyadh: Dār al-'Āṣima, 1419/1999.

3. Istiqāma=al-Istiqāma. Edited by Muhammad Rashād Sālim. 2 vols. Al-Madīna: Jāmi'at al-Imām Muḥammad b. Sa'ūd, 1403/1983.

4. Manțiqiyyīn=al-Radd 'alā l-manțiqiyyīn. $3 d$ ed. Pakistan, Lahore: Idārat Tarjumān al-Sunna, 1396/1976.

5. *Shādhilì=al-Radd' 'alā al-Shādhilī fì ḥizbayhi wa-mā șannafahū fì ādāb al-țarīq. Edited by ‘Alī al-'Imrān. Makkah: Dār 'Ālam al-Fawā'id, 1429/2008.

6. *Talbīs=Bayān talbīs al-jahmiyya fì ta'sīs bida'ihim al-kalāmiyya. Edited by Yaḥyā al-Hunaydī et al. 10 vols. Al-Madīna: Majma' al-Malik Fahd, 1426/2005.

7. *Dar'=Dar' ta'āruḍ al-'aql wa l-naql. Edited by Muhammad Rashād Sālim. 2d ed. 11 vols. Riyadh: Jāmi'at al-Imām Muhammad b. Sa‘ūd, 1411/1991.

8. *MF; sigle $\mathbf{F}=$ Majmū' fatāwā Shaykh al-Istām Ahmad ibn Taymiyya. Edited by 'Abd al-Raḥmān Muḥammad Qāsim. 37 vols. Al-Madīna: Majma' al-Malik Fahd, $1416 / 1996$.

a. Ibn 'Arabī, MF, 2:240-48.

b. Tadmuriyya=al-Risāla al-tadmuriyya, $M F$, 3:1-128.

c. Wașiyya=al-Wașiyya al-kubrā, $M F$, 3:363-430.

d. Salaf=Madhhab al-salaf fi-l i'tiqād, $M F$, 4:1-191.

e. Khalq=Createdness of the spirit [the main text of this paper], $M F, 4: 216-31$.

f. Hamawiyya=al-Fatwā al-ḥamawiya al-kubrā, $M F$, 5:5-121.

g. Nuzūl=Sharḥ hadìth al-nuzūl, MF, 5:321-585.

h. Maqālāt=Maqālāt al-țawā’if wa mawādduhum, $M F$, 6:51-61. 
i. Nafs=Mas'ala fi-1 nafs wa-l 'aql, $M F$, 9:271-305.

j. 'Ālam= On a sufi gathering at a mosque, $M F, 11: 85-103 .{ }^{16}$

k. Ikhlāṣ=Sūrat al-Ikhlās, $M F, 17: 5-504$.

1. I'tiṣām=Qā'ida nāfi'a fī wujūb al-i'tṣām bi-l risāla, $M F$, 19:93-105.

m. 'Imrān=Sharḥ ḥadīth 'Imrān b. Hușayn, MF, 18:210-44.

n. Maqābir=al-Jawāb al-bāhir fī zuwwār al-maqābir, $M F$, 27:314-44.

9. *Minhāj=Minhāj al-sunna al-nabawiyya fī naqụ kalām al-Shì'a al-qadariyya. Edited by Muḥammad Rashād Sālim. $1^{\text {st }}$ ed. 9 vols. Riyadh: Jāmi'at al-Imām Muham$\operatorname{mad}$ b. Sa'ūd, 1406/1986.

\section{Coming To Terms With Ibn Taymiyya's Epistemology and Terminology}

One perplexing aspect of Ibn Taymiyya's scholarship in Khalq is scripturalism, which he adopts to address a philosophical issue. At the end of this work, he states that human knowledge is limited and yet the fraction of that knowledge with which people are endowed should be guided by divine revelation, especially on matters related to the soul, which is from God's command. In the middle of this work, he cites multiple canonical texts to support his position on the soul's createdness. At the beginning, he invokes as authoritative the consensus of the ancients of the Muslim community (Salaf) in identifying some issues at stake in the ontology of the soul. ${ }^{17}$ Here he dwells largely upon quotations from theologians, traditionists, and mystics, while considering those who hold opposite views as the "heretics of this community." 18

In addition to Macdonald's and Langermann's notes on Ibn Taymiyya's methodology, we learn from Hilmī that Ibn Taymiyya's position on the soul constitutes a "religious" theory inspired by the Sharīa. ${ }^{19}$ In his study of a Taymiyyan treatise on the world's eternity, Hoover observes that 'Imrān represents a "philosophical inter-

16 "Ālam" is used here to indicate an exact argument in this text.

17 For Ibn Taymiyya's concept of the ancients' consensus, see Shahab Ahmed, "Ibn Taymiyyah and the

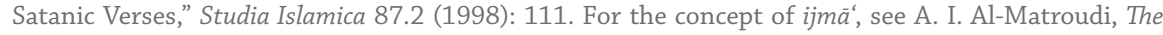
Hanbali School of Law and Ibn Taymiyyah: Conflict or Conciliation (London: Routledge, 2006), 57-59.

18 Khalq, $M F, 4: 221$

19 See Mușțafa Hilmī's foreword to the Arabic translation of Henri Laoust, Naẓariyyāt Shaykh al-Islām Ibn Taymiyya fi l-siyāsa wa l-ijtimā'=Essai sur les doctrines sociales et politiques de Takī-d-Dīn Ahmad b. Taimīyah, trans. Muhammad 'Abd al-'Az̄ìm ‘Alī, 2 vols. (Cairo: Dār al-Anșār, 1396/1976), 1:110-11. 
pretation and defence of tradition." ${ }^{20}$ Ibn Taymiyya's appropriation of philosophical discourse helps to appreciate his engagement with philosophers and speculative theologians by using their own jargon.

It has been argued that "God's essence" is an important analytical concept in Ibn Taymiyya's overall argument in Khalq. This concept features in Ibn Hanbal's Christology argument and in al-Nahrajürî's argument against incarnationist eternalists. As will be shown below, each argument marshaled in Khalq is meant to salvage and uphold the idea of God's essence. Basically, the soul both originates from and returns to God, as Ibn Taymiyya's eschatology outlines. He believes that the doctrines of pantheism, monism, and incarnation, as well as their underpinnings, compromise God's essence and human morality.

Although his approach implies that God's essence is indefinable, Ibn Taymiyya nevertheless considers it identical with God's attributes. Any God-human assimilation of the essence and attributes is unorthodox. The word "essence" itself (Ar. $d h \bar{a} t)$ presents a challenge: It is feminine. To some linguists, among them Ibn Barhān (d. 456/1064) and al-Jawālīqi (d. 540/1145), it cannot be used in reference to God without being associated with other words, for each word combination would produce an expression of one of God's attributes. In this respect, "God's essence" would be identical with "God's knowledge," "God's power," "God's mercy," and so on. ${ }^{21}$ Now, if rational theologians were to inquire how God, for instance, seats Himself upon the Throne, Ibn Taymiyya challenges them to speak of the how-ness of God's essence (kayf ${ }^{a} H u w^{a}$ fi dhätih ${ }^{i}$ ?). Therefore, one would have to conclude that the impossibility of identifying God's essence with human essence entails the impossibility of identifying God's attributes with human attributes. ${ }^{22}$

Owing to their finite knowledge, humans cannot apprehend the essence of their own souls. Ibn Taymiyya contends that whereas God's essence is identical with God's attributes, the human soul is not identical with the human body. Shaykh al-Islām's position on the soul is "midway between reductionists and assimilationists," meaning that the soul is neither immaterial, as philosophers claim, nor is it part of the body like blood, as some theologians claim. "We rather believe," he writes, "that the spirit is an entity that exists differently from the body. It is not identical with the body. It is described with what the texts really say about it, not

20 Jon Hoover, "Perpetual Creativity in the Perfection of God: Ibn Taymiyya's Hadith Commentary on God's Creation of this World," Journal of Islamic Studies 15.3 (2004): 84 [hereinafter "Perpetual"].

21 Dar', 10:157.

22 Hamawiyya, MF, 5:114. 
metaphorically." ${ }^{23}$ Likewise, Ibn Taymiyya's position on God's attributes is midway between that of the reductionists, who strip God's essence of its attributes, and that of the assimilationists, who liken God's attributes to human attributes. Thus, in another context, he says: "If the creature is exonerated of likeness to [another] creature despite concordance in name, then the Creator is all the worthier of being exonerated from likeness to a creature even if there is concordance in name."24

Throughout Khalq, Ibn Taymiyya holds that the "spirit" is created as opposed to being coeternal with God's essence. He first indicates that "soul" is interchangeable with "spirit" in the Eschatology argument, in which he cites canonical texts on death and its aftermath. This principle, namely, the soul's separation from the body at death, defines his position on the spirit in other works, notably Nafs. ${ }^{25}$ Following this approach, "soul" and "spirit" will be used interchangeably in this introduction.

Now, if the soul is neither immaterial nor part of the body, as indicated above, then what is it? In Khalq, Ibn Taymiyya maintains that the spirit is "a self-subsisting entity; it goes and comes, and it is subject to bliss and torment." 26 This short description unravels his treatment in Nafs, where we learn more about his middle position. The philosophers' notion of the soul reduces it to an immaterial substance that only recognizes universals and makes rational choices, as Avicenna (d. 428/1037) maintains. ${ }^{27}$ Ibn Taymiyya seems to share their view that the soul does not belong to the species of recognizable bodies that occupy space. However, he avers that it can be pointed to (yushār $r^{u} i l a y h^{\bar{a}}$ ), ascends and descends, gets out of the body, and is seized out of it. ${ }^{28}$ Here, he uses canonical texts to define his position, as opposed to the works of philosophers, who consider the soul just as eternal as the Necessary Being. For Ibn Taymiyya, however, an entity stripped of its attributes is an impossible being.

Although he describes the soul as self-subsisting, thereby converging with al-Ghazālī, who nevertheless considers the soul to be immaterial, ${ }^{29}$ Ibn Taymiyya

23 Ibid, 5:116.

24 Tadmuriyya, MF, 3:33; translated in Jon Hoover, Theodicy of Perpetual Optimism (Leiden: Brill, 2007), 66 [hereinafter Theodicy].

25 Nafs, $M F, 9: 272 \mathrm{ff}$.

26 Khalq, $M F, 4: 227$

27 Dimitri Gutas, “Avicenna: The Metaphysics of the Rational Soul," The Muslim World 102.3-4 (2012): 418.

28 Mas'ala, MF, 9:301-302.

29 Taneli Kukkonen, "Receptive to Reality: Al-Ghazāli on the Structure of the Soul," The Muslim World 102.3-4 (2012): 542, based on Frank Griffel, Al-Ghazālī’s Philosophical Theology (New York: Oxford University Press, 2009), 285. Also see Frank Griffel, “Al-Ghazālī's Unspeakable Doctrine of the Soul: 
highlights the importance of its relation to the body in matters of sensation and accountability and concludes that it is a physical being within the body. Thus, he disqualifies the assumption that the "soul" and the "spirit" are essences that subsist independently of the body. ${ }^{30}$ But he does not stop here, for elsewhere he disputes the "greatest proof" advanced by the philosophers to argue for the soul's immateriality: Knowledge inheres in it. If the soul were material, it would be subject to division and thus knowledge would be subject to division. This scenario is impossible, if universals, for instance, are the object of knowledge. Ibn Taymiyya responds to this proof in five points.

First, knowledge subsists in the soul, just as life, power, will, love, and hate subsist in it. Therefore, that which applies to these accidents also applies to knowledge. Second, al-Ghazālī falsified the claim that everything that inheres in a body must be divisible, arguing that the estimative power discerns that which is intangible within a tangible object, such as a sheep's apprehension of the wolf's enmity. ${ }^{31}$ Third, knowledge, power, life, and other accidents subsisting in the soul remain only if the soul remains, just as the accidents of life, power, and sensation subsisting in the body remain only as long as the body is alive. Fourth, universals do not exist entirely in the external reality; they exist also in the minds. Fifth, some loci, among them the soul, cannot undergo division. While some Mu'tazilīs, Ash'arīs, and Karrāmīs believe that the soul is composed of single substances, some philosophers hold that it is composed of material and form. Thus, Ibn Taymiyya passes a judgment here. He thinks that the philosophers' claim that the soul is not a physical being is both correct (because they deny that it is composite and divisible) and incorrect (they assert that all sentient objects to which one can point are composite and divisible). Since they claim that everything to which one can point is a body and that a body is composed as such, they have to conclude that the soul cannot be pointed to physically.

Unveiling the Esoteric Psychology and Eschatology of the Ihyä' by Timothy J. Gianotti," Journal of the American Oriental Society 124.1 (2004): 109. Ibn Taymiyya seems to be referring to al-Ghazāli's piece: "The truth about the essence of the soul is that it is self-subsisting. It is neither an accident, nor a physical being, nor an essence occupying space. It does not inhere in a place or direction. It is not attached to the body and the world, nor is it disengaged from [both]. It is not included in the worldly bodies" (Nafkh al-rūḥ wa l-taswiya, ed. Aḥmad Ḥijāzī al-Saqqā [Cairo: Maṭba'at Dār al-Bayān, 1399/1979], 35.) For the corresponding passage, see Tadmuriyya, MF, 3:31.

30 Shādhilī, 128.

31 Abū Hāmid Al-Ghazālī, The Incoherence of the Philosophers, trans. Michael E. Marmura (Utah: Brigham Young University Press, 2000), 182-83. For Ibn Taymiyya's summary of this argument, see Dar', 10:294. 
In summary, Ibn Taymiyya asserts the soul's physicality, saying that it is tangible because it sees, smells, tastes, and hears via the body's agency. Thus the soul and the body affect each other. In other words, when the soul experiences love, satisfaction, happiness, or sadness, such experiences affect the body. Also, when the body is hot or cold, hungry or satiated, such experiences, in turn, affect the soul. Since the body is specific to one entity, it only affects the soul that is associated with it. Thus the body must indicate and identify this particular soul. The indicator is physical, and thus the soul is also physical. ${ }^{32}$

\section{Ibn Taymiyya's Arguments for the Soul's Createdness}

Having addressed the first problem by coming to terms with Ibn Taymiyya's basic analytical concepts in Khalq, we now address the second problem: the arguments underlying his position on the soul's createdness and the implied opposite views. These can be gleaned primarily from Khalq, with explications from some of his other works. In Khalq, Ibn Taymiyya is especially ambivalent about his double categorization of the holders of opposite views in MF, 4:221-22. Only the second category will be addressed here, for it is quite germane to this paper's overall argument. ${ }^{33}$ Something shall be said about his authorities in Khalq before rescuing the content of their statements, which underlie his multilayered argument therein.

In Minhāj, Ibn Taymiyya provides a hierarchy of referential authorities through which the disciplines of Islamic knowledge were communicated from the first/ sixth century to the fifth/eleventh century. ${ }^{34}$ Some of these authorities appear in Khalq. Considering the authorities cited in Khalq, one wonders if the doctrine of the soul in classical scholarship, as outlined in Ibn al-Qayyim's famous Kitāb alrūh. ${ }^{35}$ is heavily influenced by Ibn Taymiyya's Hanbalī sources. Indeed, in Khalq Ibn Taymiyya tends to cite authorities who are associated with Hanbalism. However, the reality is more complex than school affiliation. For one thing, his background is

32 Dar', 10:293-98.

33 The first category has induced extensive research on the Sabian philosophers, the origination of worldly bodies, and causality. As these subjects make this paper unnecessarily long, they will be dispensed with. For God's creation of this world in Ibn Taymiyya, see Jon Hoover, "Perpetual."

34 Minhāj, 7:425-28.

35 Francis Cooke speaks of "the belief of the great majority of Muslims" ("Ibn al-Qaiyim's Kitāb al-Rūḥ," 129), and E. Calverley speaks of "the dominant Muslim doctrine" ("Nafs," $E I^{2}, 7: 882$ ) of the soul as constituted by this work. 
too rich to be described as merely Hanbali. For example, the diversity of the voices cited therein allows us to hear not only from jurists, traditionists, and theologians, but also from mystics. ${ }^{36}$

Five major arguments can be rescued from the authorities chosen to defend his position on the human soul's temporal origination, with a view to upholding the idea of God's essence. Listed in the order of their appearance, they are: the Christology argument, the Covenant argument, the Antinomianism argument, the Eschatology argument, and the Linguistic argument. As Ibn Taymiyya does not say that he is presenting this or that argument, the reconstruction attempted here reflects my own interpretation of Khalq in light of his other works.

The Christology argument (MF, 4:217-20) is especially important for two reasons: He 1) cites it from Ahmad b. Hanbal (d. 241/855), the progenitor of Hanbalism, who is historically known for his unfaltering position on the uncreatedness of the Qur'ān ${ }^{37}$ and 2) invokes it in the background of an encounter between Jahm b. Șafwān (d. 128/746) with the Sumaniss on the human soul's immateriality. Ibn Hanbal argues that Christology inspired Jahm's position.

Concerning the second point, we read in Dar' that the Sumanis (i.e., Indian Buddhists) were like those Greek naturalist philosophers who negated incorporeal existence and therefore believed only in sentient beings. In their debate with Jahm, they wondered if he could perceive God by any of the five senses. Jahm furnished a response that apparently maintained God's Holiness-He cannot be predicated on spatial terms - simultaneously concluding that the soul is immaterial. Inspired by "Christian heretics," so Ibn Taymiyya says, those who believe that the spirit of Jesus is the spirit of God and is from God's essence, Jahm argues that the rational soul is immaterial, just as God exists but cannot be seen, heard or smelled. ${ }^{38}$

36 Michot published a collection of spiritual texts in Ibn Taymiyya against Extremisms (Paris: Albouraq, 2012) [hereinafter Extremisms] to provide an alternative reading of this Damascene theologian, who is frequently considered a source of inspiration for Islamic terrorists. His reading could also be a revision of Massignon's claim that Ibn Taymiyya was anti-sufi. Mușțafā Hilmī studied Ibn Taymiyya's spirituality in response to Massignon and other Orientalists in Ibn Taymiyya wa-l tașawwuf (Alexandria: Dār alDa'wa, 1982). The pioneer revisionist of Ibn Taymiyya's anti-mysticism was Henri Laoust in his Essai, followed by George Makdisi, who argued that Ibn Taymiyya himself was a Qādirī șūfĩ in "Ibn Taymiyya: A Sufi of the Qadiriya Order," American Journal of Arabic Studies 1 (1973): 118-29. For some of Ibn Taymiyya's views on Sufism, see Th. E. Homerin, "Ibn Taimīya's al-Ṣūfĩyah wa-al-Fuqarā'," Arabica 32, (1985): 219-44.

37 See Richard Martin, “Createdness of the Qur'ān," in Encyclopaedia of the Qur'än, ed. Jane Dammen McAuliffe (Leiden-Boston-Köln: Brill, 2001), 1:467-71.

38 Dar', 5:165-71. 
Ibn Taymiyya considers Jahm a victim of misrepresentation, since the unbelieving Sumanī interlocutors confused him: "They made him think that humans cannot recognize what they do not perceive, as if the principle is that what is not sentient is not recognizable." ${ }^{39}$ However, the victimized Jahm produced another argument that is pertinent to the first justification above, using analogical reasoning: The Qur'ān is created because Jesus is created. Citing Q4:171, he argues that Jesus is God's word and a spirit from Him, but he is created, and because the Qur'ān is God's word, it is likewise created. Ibn Hanbal disqualifies this response on the grounds that Jesus was originated by the agency of God's word, which is primordially uncreated. The implication of this exchange is that the spirit of Jesus is likewise originated by God's command and so cannot be coeternal with God's essence. Therefore, his divinity is excluded.

Cited after Ibn Hanbal's Christology is Abū Sa'īd al-Kharrāz (d. 286/899), a proponent of the Covenant argument. ${ }^{40}$ Wilferd Madelung intimates that al-Kharrāz, like al-Junayd (d. 298/910), "tried to combine a doctrine of ecstatic mysticism with orthodox support of religious law." ${ }^{41}$ In Khalq, al-Kharrāz argues that creationism and lordship prove the createdness of the spirit. He cites the Covenant ( $m \bar{i} t h \bar{a} q$ ) verse: "And when your Lord took from the children of Adam-from their loins - their descendants and made them testify of themselves 'Am I not your Lord?' They said, 'Yes, we have testified'" (Q7:172). This verse indicates the concept of fitra, which especially here means the start of the creation process in the womb, as Ibn Taymiyya cites from Ibn Hanbal. ${ }^{42}$

Also, al-Kharrāz relates his argument to the createdness of Jesus' soul: "If the [spirits] had been uncreated, the Nazarenes would not have been blamed for wor-

39 Țawä’if, FK, 6:364-65.

40 Khalq, MF, 4:220-21.

41 Wilferd Madelung, "al-Kharrāz," $E I^{2}, 4: 1083$. Some of al-Kharrāz's mystical views are presented in Binyamin Abrahamov, Ibn al-Arabi and the Sufis (Oxford: Anqa Publishing, 2014), 63-67.

42 Dar', 8:359-60. See Jon Hoover, “Fițra," in Encyclopcedia of Islam, 3d ed., 2:104-06. From Ibn Taymiyya's perspective in relation to human reason and the perfection of fitra through prophecy, see Hoover, Theodicy, 39-44. On human free will in relation to predetermination, see Livnat Holtzman, "Human Choice, Divine Guidance and the Fițra Tradition: The Use of Hadith in Theological Treatises by Ibn Taymiyya and Ibn Qayyim al-Jawziyya," in Ibn Taymiyya and His Times, 163-88 and footnote. 46 for identification of three Taymiyyan works on the topic. On the rationale of divine creationism vis-à-vis human free will and agency, see M. S. Özervarli, "Divine Wisdom, Human Agency and the fițra in Ibn Taymiyya's Thought," in Islamic Theology, Philosophy and Law: Debating Ibn Taymiyya and Ibn Qayyim alJawziyya, ed. Birgit Krawietz and Georges Tamer (Berlin: de Gruyter, 2012), 38ff [hereinafter "Divine Wisdom"]. For a recent disquisition, see Yasir Kazi, "Reconciling Reason and Revelation in the Writings of Ibn Taymiyya (d. 728/1328): An Analytical Study of Ibn Taymiyya's Dar' al-ta ‘āruḍ” (PhD diss., Yale University, 2013), 232-92. 
shipping Jesus, nor when they said that he is the son of God and said that he is God." ${ }^{43}$ Ibn Taymiyya builds on this argument to markedly conclude that everything proving man's servanthood, creation, and subjection to God demonstrates that man's spirit is originated.

Like al-Kharrāz, Abu Ya'qūb al-Nahrajūrī (d. 330/941) is a major mystical authority. He is cited in Khalq as an advocate of the Antinomianism argument. ${ }^{44} \mathrm{His}$ mysticism is particularly opposed to the moral decadence arising from the hedonism of those who believe in the oneness of being. Hagiographical works indicate a relationship between him and the famous al-Hallāj (d. 309/922) that ended with the former's condemnation of the latter as having been "served by demons." For this doctrinal reason, they parted company. ${ }^{45}$ This reference expounds al-Nahrajūrī's hostility toward eternalists "who end up in antinomianism." It also invites reflection upon the creed of al-Hallāj, one of his foremost adversaries.

Ideologically speaking, al-Hallāj is famous for his theopathic utterance "I am the Truth." ${ }^{46}$ Ibn Taymiyya relates this identification with the Divine to the Christian claim of Jesus' divinity and to the Muslim exaggerators' claim of the divinity of 'Alī b. Abī Ṭālib (d. 40/661) and al-Ḥākim the Fāțimid (d. 411/1021). ${ }^{47}$ Despite these connotations, Ibn Taymiyya finds in other statements made by al-Hallāj a refutation of the soul's eternity. Al-Hallāj said: "Everything that is assembled by means of an intermediary is held together by its powers." ${ }^{8}$ "This is a response," comments Ibn Taymiyya, "to those who speak of the spirit's eternity or of the Creator's indwelling in the created." For him, bodily organs are an intermediary or a tool (adāh) whereby the human being is assembled, and their powers hold man together. Man's need of these tools and powers means that man is not self-sufficient and is, therefore, not divine. ${ }^{49}$ Thus this lack of self-sufficiency, as indicated by al-Hallāj's counterargument, implicates the origination of the human soul, for eternity is an exclusive attribute of the self-sufficient God.

\footnotetext{
43 Khalq, MF, 4:220.

44 Ibid, 4:221.

45 See Shams al-Dīn al-Dhahabī (d. 748/1347), Tārīkh al-islām wa wafayāt al-mashāhīr wa l-a'lām, ed. Bashshār Ma'rūf, 17 vols. (Beirut: Dār al-Gharb al-Islāmī, 1423/2003), 7:587 [hereinafter Tãrīkh]; See L. Massignon, Hallaj: Mystic and Martyr, trans. and abridged by Herbert Mason (New Jersey: Princeton University Press, 1994), 52-58 and Herbert Mason, Al-Hallaj (London and New York: Routledge, 1995), 52.

46 L. Massignon [G. C. Anawati], "al-Halläj," EI², 3:100.

47 Yahya Michot, "Ibn Taymiyya's Commentary on the Creed of al-Hallāj," in Sufism and Theology, ed. Ayman Shihadeh (Edinburgh: Edinburgh University Press, 2007), 126.

48 Alexander Knysh, trans. Al-Qushayrî's Epistle on Sufism=al-Risala al-qushayriyya fi 'ilm al-tasawwuf (Reading, UK: Garnet Publishing Ltd., 2007), 6.

49 Istiqāma, 1:124.
} 
This exception, however, does not supersede the doctrine of Divine love, which jeopardizes the uprightness of human behavior. The uncalculated love of God espoused by al-Hallāj might lead to immorality, understood as the monists' disregard for ethical boundaries. This pattern verges on heterodoxy. Part of Ibn Taymiyya's legacy is concerned with refuting this type of belief and its implications. ${ }^{50}$ Henri Laoust, the pioneer of Taymiyyan studies, observes that the Hanbalis responded to a need for moralism and that Ahmad b. Hanbal's doctrine was dominated by ethical preoccupations. ${ }^{51}$ Hoover likewise writes: "Ibn Taymiyya often concerns himself with the ethical implications of theological doctrines. This is especially apparent when he traces the sources of antinomian practices." ${ }^{2}$

Following the Antinomianism argument, eschatology and linguistics are invoked with a special Taymiyyan flavor. On the one hand, the Damascene theologian assembles multiple canonical texts only to let them speak for themselves. His scripturalism, as I stated above, is perplexing and, therefore, his canonical citations in Khalq need to be explained. On the other hand, he provides a kind of philosophy of the language to advance his position on the soul's origination. Toward this end, the contours of the argument require an interdisciplinary investigation of pertinent exegetical, theological, mystical, and historical aspects.

The Eschatology argument (MF, 223-26) presents us with the problem of eschatological scripturalism spelled out in several quotations from the Qur'àn and hadith about death and postmortem experiences. Marcia Hermansen notes that eschatology is a combination of individual and cosmic elements that link humanity's fate to the purpose and destiny of creation. She states that it is significant "because of the qur'anic stress on the intelligibility of history as well as on individual human accountability." 53 The background of this note can be found in God's saying: "Did you think that We created you uselessly and that to Us you would not be returned?" (Q23:115) Concerning this verse, Ibn Taymiyya quotes al-Tha'labī (d. 427/1035) through his isnād that Ja'far b. Muḥammad al-Ṣādiq (d. 148/765) was once asked: "Why did God create the creation?" He replied that God created

50 See, for example, Talbīs, 5:212 and Ibn 'Arabì, MF, 2:244. Also see Wael Hallaq, Ibn Taymiyya against the Greek Logicians (New York: Oxford University Press, 1993), xii-xiv; Alexander Knysh, Ibn 'Arabi in the Later Islamic Tradition (Albany: State University of New York Press, 1999), 99ff; Michot, Extremisms, 67-82; Muhammad Memon, Ibn Taimìya's Struggle against Popular Religion (Paris and The Hague: Mouton, 1976), 44.

51 See Henri Laoust, "Hanābila," $E I^{2}, 3: 158$.

52 Hoover, Theodicy, 23

53 Marcia Hermansen, "Eschatology," in The Cambridge Companion to Classical Islamic Theology, ed. Tim Winter (New York: Cambridge University Press, 2008), 309. 
people out of absolute, never-ceasing beneficence and sent them messengers to distinguish between truth and falsehood. Al-Ṣādiq follows up with an eschatological note: Obeying God leads to enjoyment in His Garden, and disobeying Him leads to suffering in His Fire. ${ }^{54}$

This exegetical comment shows what is at stake in history and cosmology in relation to human behavior and accountability. God creates humans for a purpose and they ultimately return to Him. Likewise, God maintains divine guidance by sending messengers, which means that prophecy perfects cosmology. ${ }^{55}$ If this were not the case, then creation would have been aimless. ${ }^{56}$ Ibn Taymiyya states that messengers were sent to establish theological (God's oneness and attributes, etc.), legal (ethics), and eschatological (destination and recompense) principles, all of which justify God's "creation (khlaq) and command (amr)." Also, the "happiness and success" of humans are contingent upon them. ${ }^{57}$

Complementing creation with prophecy makes history intelligible. The same relation applies to humanity's fate and accountability. These dynamics are at work in the canonical texts that Ibn Taymiyya quoted in Khalq. He cited them to prove that the soul is created, for they represent the duality of reward and punishment as spiritual and physical experiences in the afterlife. Through this proof, he sought to strike a balance by neutralizing the religious experience so that it would not be taken as purely spiritual. He also aimed to tame the indulgence of materialists. Furthermore, he presented these texts as a likely response to the Avicennan claim that the "outer meaning of the laws cannot be used as an argument" in matters like eschatology and theology. ${ }^{58}$ By this usage, Avicenna invites an understanding of the eschatological vocabulary appropriate to the elites, who should take these ideas metaphorically, whereas the common people are expected to understand them literally.

Ibn Taymiyya also cites a parable on the body-soul accountability for evildoing, ${ }^{59}$ a trope that is found in his other works. For example, in one place he says:

55 Commenting on a hadith saying that if it were not for Muhammad, God would not have created the spheres (lawlākā mā khalaqtu al-aflāka), Ibn Taymiyya says, "If the best of the righteous of Adamic beings is Muhammad, and [if] the creation of him is an objective that is desired and a perfect wisdom that is contemplated, and [if] he is [more honorable] than anyone else, then the perfection of creation and the consummation of perfection is fulfilled through Muhammad ('Ālam, MF, 11:97)."

56 On the divine wisdom in creation, see Özervarli, "Divine Wisdom," $40 \mathrm{ff}$.

57 I'tișām, MF, 19:96.

58 Yahya Michot, "Revelation," in The Cambridge Companion to Classical Islamic Theology, 192.

59 Khalq, MF, 4:222-23. 
"The rectitude of the heart and the tongue involves the rectitude of both the spirit and the body. Since the body is paired with the spirit, the body cannot act voluntarily except with the participation of the spirit." 60 In another place, he comments on the parable-tradition: "Those who call [the spirit] 'rational soul' agree that it is associated with the body to attain its perfections." ${ }^{11}$ Here, Ibn Taymiyya argues theologically for what Avicenna argues for philosophically: To attain perfection, the soul needs to clothe itself with matter (i.e., the body). An Avicennan specialist writes: "The soul can only become perfect by existing in the body and having the sense experiences that provide the opportunity for abstraction." ${ }^{2}$ On the other hand, a Bașran Mu'tazili holds that rationalists "know that it is this body who deserves blame for its evil acts and praise for doing good." 63 So, the Eschatology argument, meant to prove the soul's origination, has shown Ibn Taymiyya's literalism versus rationalism in approaching canonical texts.

Further to his noted contributions so far, Ibn Taymiyya employs linguistic subtleties in the last argument ( $M F, 4: 226-30)$ to support his theological position. His hermeneutical engagement with Q17:85 is guided by Arabic grammar. Earlier in Khalq (MF, 4:220), he includes a significant part of Ibn Hanbal's argument on relation (id̄a fa), a concept that Ibn Taymiyya appropriates in his other works to essentially argue for the eternity of God and His attributes, as well as for the temporal origination of everything else. Reconstructing the contours of the relation argument will explain what he means by the second category of those who uphold the opposite view. ${ }^{64}$

Ibn Taymiyya is aware that divine revelation is better understood through the mechanism of Arabic syntax. Commenting, therefore, on "the spirit is from the command of my Lord (al-rū h. min amri Rabbī)" (Q17:85), he says that "spirit" means either an angel or the human spirit. However, neither meaning implies that the spirit is eternal. He justifies this stance by analyzing the term "command" (amr) grammatically. It could be either a verbal noun (commanding) or an object (something commanded). ${ }^{65}$ Since the spirit, in Ibn Taymiyya's definition, is a self-subsist-

\footnotetext{
60 Shädhilī, 125.

61 Talbis, 6:562-64.

62 Peter Adamson, "Correcting Plotinus: Soul's Relationship to Body in Avicenna's Commentary on The Theology Of Aristotle," Bulletin of the Institute of Classical Studies 47 (2004): 67-69; quotation 68.

63 Wilfred Madelung, "Ibn al-Malāhimī on the Human Soul," The Muslim World 102.3-4 (2012), 427.

64 Khalq, $M F, 4: 220$

65 For the same distinction concerning the world being a matter and command, see Jon Hoover, "Perpetual," 305. Cf. 'Imrān, MF, 18:215.
} 
ing entity, it is subject to God's command and lordship, as well as to the divinely promised bliss or torment after death. Even theologians who believe that the spirit is an accident subsisting in the human body think that it is from God's command.

In this respect, he justifies this interpretation with three authorities cited in Khalq. The first authority is al-Kharrāz, who says: "The command of God Most High is what is commanded and brought into being by the agency of the One Who brought it into being." 66 This note does not appear in the Covenant argument, cited earlier in Khalq. The second authority is Ibn Hanbal who has already stated that Jesus was created by the agency of God's word and that he himself is not the word. The third authority is Ibn Qutayba (d. 276/889), who maintains that the spirit is related to God because it comes into being by God's command or word.

Apart from these Khalq authorities, the Qur'ānic commentator Ibn 'Ațiyya (d. 542/1147) might have influenced Ibn Taymiyya's syntactical explanation. In his exegesis, this Andalusian exegete says that "the spirit is from the command of my Lord" and that "command" (amr) typifies the spirit, which is among the things that are known to God alone. In this sense, the spirit is related to God, just as a creation is related to the Creator. Alternatively, "command" is a verbal noun of amara and ya'muru, thereby meaning that the spirit came into being by God's word or command: "Be/Come into being." ${ }^{67}$ We find a very concise inspiration for Ibn 'Ațiyya's double interpretation in al-Wāhidì (d. 468/1076) who, commenting upon this part of Q17:85, maintains that "the spirit is from the command of my Lord" means that "it is from my Lord's knowledge (so you do not know it); from my Lord's creation (i.e., created by Him)."68

Fakhr al-Dīn al-Rāzī (d. 606/1210) gives a brilliant explanation in his exegesis: "God's command" stands for "God's action." This he further explains as "God's formation and bringing into existence." He thus concludes that the Jews asked Prophet Muhammad whether the spirit is eternal or originated. In response, al-Rāzī suggests, the Prophet said that it is originated. Al-Rāzì considers "knowledge" at the verse's end- "and you were not given of knowledge except a little"-a proof of his exegetical note. In the primordial state of fițra (natural constitution), the spirit is

66 Khalq, MF, 4:228.

67 Ibn 'Ațiyya al-Andalusī, al-Muharrar al-wajīz fì tafsīr al-Kitāb al-'Azīz, ed. 'Abd al-Salām 'Abd al-Shāfī, 5 vols. (Beirut: Dār al-Kutub al-'Ilmiyya, 2001/1422), 3:481. Ibn Taymiyya says, "Ibn 'Ațiyya was more knowledgeable of Arabic grammar and semantics than these [especially al-Zajjāj (d. 311/923) the exegete] and more expert in the grammatical opinions of Sibawayh and the Basrans" (MF, 27:431).

68 Abu-l Ḥasan al-Wāḥidī, al-Wajīz fĩ tafsīr al-Kitāb al-'Azīz, ed. Ṣafwān A. Dāwūdī (Beirut: Dār al-Qalam and Damascus: al-Dār al-Shāmiyya, 1415/1994), 646. 
void of all sciences and knowledge and only acquires them later in time. Attaining perfection through knowledge after a state of deficiency marked with ignorance indicates that the soul is originated. ${ }^{69}$

Furthermore, Ibn Taymiyya posits that the preposition "from" in "from ( $\mathrm{min}$ ) the command of my Lord" indicates either genus (jins) or starting point (ibtidä' alghāya). He says that the second meaning applies to the spirit, having been started from God and formed by His command, and thereby created. Again he invokes Ibn Hanbal's Christology, such that the spirit was breathed into Jesus from God's command. Although self-subsisting entities originate from God's command, they are not coeternal with God's essence because God's command is one of God's attributes, all of which are eternal.

The Linguistic argument continues with another linguistic subtlety, namely, relation (id̄a fa), which Ibn Taymiyya gleans from Ibn Hanbal's response to Christianity concerning the relating of Jesus to God's essence: "Relating the spirit to God is a relation of ownership and creation," rather than a "relation of an attribute to the being thereby described." I0 Ibn Taymiyya's corpus includes commentaries on this particular theme, ${ }^{71}$ which also resolves his ambiguity about the second category of those who opposed his view on the soul.

In Dar', Ibn Taymiyya identifies two groups as misguided about relating things to God: 1) Those who, including the negators of God's attributes like the Jahmīs and Mu'tazilīs, considered everything related to God to be created by Him and subject to His lordship, and 2) those who, including some incarnationist Sunnis, considered things related to God to be God's attributes. He contends that both groups consider "God's word" to be equal to "a spirit from Him." In other words, God's eternal speech is identical with God's creation, which is originated by the agency of God's word. However, the negators of God's attributes say that both the human spirit and God's words are created and therefore distinct from God. Also, the incarnationists say that as God's word is one of God's attributes, it does not belong to created beings. Thus they conclude that the spirit, which they hold is from God, is an uncreated attribute of God. ${ }^{72}$ 
Interestingly, Ibn Taymiyya includes Ḥanbalī theologians, such as Ibn 'Aqīl (d. 513/1119) and Ibn al-Jawzi (d. 597/1200) in the first group. ${ }^{73}$ Both, according to him, said that certain Qur'ānic verses were "verses of relations (āyāt al-idāfāt), not verses of attributes (āyāt al-șifät)." He also says that Ibn al-Jawzī copied Ibn 'Aqīl on this point. Mu'tazili thought is unmistakable in Ibn 'Aqil's contentions here.

In his Dar', Ibn Taymiyya maintains that Ibn 'Aqil "looked extensively into the Mu'tazili literature" and was greatly influenced by it. ${ }^{74}$ Later he says, "When Ibn 'Aqil probed the theology of the Mu'tazilis, he did not approve of their way." ${ }^{75} \mathrm{He}$ described this scholar as an outstanding theologian who had fluctuating opinions and an impact on other Hanbalīs. Along the same line, George Makdisi observes that Ibn 'Aqil was an independent thinker whose Mu'tazili inspiration gave the Hanbali movement a new direction. ${ }^{76}$ Ibn Taymiyya approvingly maintains that he was a brilliant scholar who speculated about different schools and therefore expanded his theological horizons. As a result, he would sometimes adopt the Mu'tazili approach of negating God's reported attributes (șifät khabariyya), calling them "relations" (idāfāt). From this attitude comes his influence on Ibn al-Jawzī, as will be explained shortly. Other times, Ibn 'Aqil would affirm God's attributes and blame the Mu'tazilis for their reductionism. Ibn Taymiyya equates him with al-Ghazālī, Ibn Ḥazm, and al-Rāzì, all of whom, despite their erudition, contradicted themselves. ${ }^{77}$

Concisely documenting the various theological positions on God's attributes, Ibn Taymiyya says that "a strong Mu'tazili material" would sometimes appear in Ibn 'Aqil's statements about God's attributes, predetermination, and saintly miracles, given that al-Ash'ari (d. 324/935-36) would have been closer to the Sunna in his views than he was. ${ }^{78}$ This influence naturally came from his Mu'tazili masters Abū 'Alī b. al-Walīd (d. 478/1086) and Abū l-Qāsim b. al-Tabbān (d. 419/1028). Khalid Blankinship traces the fluctuation in Ibn 'Aqil's theological loyalty to Mu'tazili-inspired Ash'arism and literalist Ḥanbalism back to his fluctuation in the state's bias

\footnotetext{
73 Henri Laoust, "Ibn al-Djawzī," $E I^{2}, 3: 751$.

74 Dar', 8:54. His fellow Hanbalì Abū Ya'lā b. al-Farrā' (d. 458/1066) was a pioneer of Mu'tazilī-inspired intellectualism. See Michael Cook, Commanding Right and Forbidding Wrong in Islamic Thought (Cambridge: Cambridge University Press, 2004), 129ff.

75 Dar', 8:59.

76 G. Makdisi, "Ibn “Akịil," $E I^{2}$, 3:699.

77 Dar', 8:60-61.

78 Maqālāt, MF, 6:53.
} 
toward certain schools. ${ }^{79}$ Ibn Taymiyya identifies some of his statements with those of al-Marīsī the Jahmiyan (d. 218/833). However, in Kitāb al-Irshād Ibn 'Aqīl affirmed God's attributes. More specifically, Ibn Taymiyya says that Ibn 'Aqiil's approach was akin to those of the early Ash'arīs and Kullābīs. In other words, he would confirm that which was proved by the Qur'àn and by contiguously transmitted reports, and, in the absence of such proof, would interpret the text metaphorically. Therefore, some Hanbalīs would say: "I affirm [God's attributes] midway between Ibn 'Aqīl's reductionism and Ibn Hāmid's (d. 403/1012) anthropomorphism." ${ }^{0}$

Now, there is evidence of Ibn Taymiyya's claims about Ibn 'Aqīl. As regards the mistakes of Hanbalī anthropomorphists, Ibn al-Jawzī says: "They called the reports (akhbār) 'reports of attributes,' although they are indeed relations (id̄āfāt). Not everything related (mudāf) [to God] is an attribute (șifa) [of Him], for God Most High says: 'And I breathed into him of My spirit.' Since there is no attribute of God called 'spirit,' those who called it an attribute have innovated." ${ }^{81}$ Blankinship confirms that Ibn al-Jawzì was a traditionist (muhaddith) who was-and still is-considered authoritative in the Hanbali school, and his anti-literalist reading of God's attributes represents "an important milestone in classical Muslim discourse about the nature of God." 82 This note explains Makdisi's observation about the new trend that Ibn 'Aqìl, a main source of inspiration to Ibn al-Jawzī, had set.

According to Ibn Taymiyya, the other misguided group in this regard claimed that relating the human spirit to God makes it eternal, as God's essence is eternal. Even though they are associated with the Muslim community, they emulate Christians in identifying Jesus' soul with God's essence. In Dar', the followers of Shaykh 'Adì belong to this category. ${ }^{83}$ This brief note calls for explanation.

In MF, Ibn Taymiyya has a work entitled "The Great Counsel” (al-Wașiyya alkubrā) or "The Sunnī Message to the "Adawī Group" (al-Risāla al-Sunniyya ilā al-țā'ifa al-'Adawiyya), a letter that he had sent to the followers of Shaykh 'Adì b. Musāfir

79 Ibn al-Jawzī, The Attributes of God: Ibn al-Jawzì's Daf'Shubah al-Tashbīh bi-Akaff (sic) al-Tanzīh, trans. 'Abd Allāh bin Hāmid 'Alī and forwarded by Khalid Blankinship (Bristol: Amal Press, 2006), vix-xv.

80 Maqūlāt, MF, 6:54.

81 See Ibn al-Jawzī, Daf shubhat al-tashbīh, ed. Muhammad Zāhid al-Kawtharī (Cairo: al-Maktaba alAzhariyya li-Turāth, n.d.), 9. For a standard version, see Ibn al-Jawzī, Daf' shubah al-tashbīh bi-akuff al-tanzīh, ed. Ḥasan Al-Saqqāf (Beirut: Dār al-Imām al-Rawwās, 1428/2007), 104. Cf. translation in idem, The Attributes of God, 47. I translate iḍaffa as "relation" throughout this paper in order to maintain consistency.

82 Ibn al-Jawzī, Attributes, xiii.

83 Dar', 7:263-64. 
al-Umawi (d. 557/1162) ${ }^{84}$ In it, he explains to them the principles and violations of Islamic belief, calls upon them to adopt a middle way in religion, and warns them against heresies and excessiveness. The letter is penned in a courteous, didactic, and connotative style, one rich in canonical texts and historical reflections. It recognizes the merits of the founder of this sufi order. ${ }^{85}$ Elsewhere in $M F$, however, Ibn Taymiyya indicates that some exaggerations of the shaykh's followers verged on monstrous unbelief. ${ }^{86}$

So, in this letter he both shows the 'Adawīs a middle way between Judaism and Christianity and condemns the doctrines of union (ittiḥadd) and incarnation ( $h u l \bar{u} l)$. He disapproves of their excessive veneration of mystics, including Shaykh 'Adī, al-Ḥallāj, and Yazīd b. Mu'āwiya (d. 64/683) ('Adawīs were later called Yazīdīs). ${ }^{87}$ Christine Allison says that the Yazidis' religion is highly cryptic and inspired by esoteric mysticism and Iranian cosmology. The editors of Shaykh 'Adì's Creed claim that Shaykh Hasan had contacts with sufi masters like Ibn 'Arabī. ${ }^{88}$ This unreferenced note explains why Ibn Taymiyya warned the 'Adawīs against monism. It is clear that he sent this letter after Shaykh Hasan's death, because he says that the shaykh was murdered and that problems emerged after his murder. Now, when he warns the 'Adawīs against heresies, he specifically mentions unionists (ittihădiyya) like Ibn 'Arabī, Ibn Sab'īn (d. 669/1270), Ibn al-Fārị̣ (d. 632/1235), al-Tilimsānī (d. 690/1291), and al-Bilyānī (d. 686/1288) as followers of Jahmīs, who claimed that God dwells in or unites with all existents, including pigs and dirt. ${ }^{89}$ This finding suggests that Ibn 'Arabī might have contacted the contemporaneous Shaykh Hasan and that a mutual pollination of esoteric ideas had occurred. Ibn Taymiyya thus might have concluded that the 'Adawīs or Yazìdis had internalized the belief in the human spirit's eternity because they identified with the incarnation inspired by the Christian deification of Jesus.

Wașiyya, MF, 3:363-430. See P. G. Kreyenbroek, "Yazīdī," $E I^{2}, 11: 313$; Christine Allison, "Yazidis," in Encyclopcedia Iranica (online edition: http://www.iranicaonline.org/articles/yazidis-i-general-1.) [hereinafter EIR]. For English translations of parts of this letter, see Michot, Extremisms, (Section 16) [MF, 3:282-88], 2-10 (Section 1) [MF, 3:369-75], 21 [MF, 3:377], 21-22 [MF, 3:410], 19-33 (Section 3) $[M F, 3: 415-25]$.

85 Wașiyya, $M F, 3: 363-430$, at 377.

$86 \quad M F, 11: 101$.

87 Wașiyya, $M F, 3: 395,410$.

88 'Adī b. Musāfir al-Hakkārī, I'tiqād ahl al-sunna wa l-jamā'a, ed. Hamdī al-Salafĩ and Tahsīn al-Dūsakī (AlMadīna: Maktabat al-Ghurabā' al-Athariyya, 1419/1998), 8. In 1216, Ibn 'Arabī returned to Anatolia "at the end of a long period of wandering through Egypt, Iraq, Palestine, and the Hejaz." See Claude Addas, Ibn 'Arabi: The Voyage of no Return, trans. David Streight (Cambridge, UK: The Islamic Texts Society, 2000 [repr. 2010]), 109. The ripple effect of Ibn 'Arabi must have been great. 


\section{Conclusion}

Here I end the introduction with a double conclusion. The first conclusion brings in a statement that is quite germane to Ibn Taymiyya's epistemology. He quotes it from al-Junayd, a mystical authority whom he highly prizes. ${ }^{90}$ In my opinion, this statement draws together all of the threads that comprise the overall argument presented in Khalq and my interpretation thereof. In Shädhilī, Ibn Taymiyya reports that when al-Junayd was asked to define tawhìd (upholding God's oneness), he stated concisely: "To uphold God's oneness is to isolate origination from eternity (al-twahì $d^{u}$ ifräd $d^{u}$ al-huudūthi 'an al-qidam ${ }^{i}$ )." Here Ibn Taymiyya appreciates al-Junayd as "a leader of guidance" and his viewpoint as an exposition of "the disease from which many [incarnationists and unionists] suffer." ${ }^{\text {19 }}$

Reflecting upon Ibn Taymiyya's approach to God's essence and its relation with God's attributes, his position on the soul's corporeality and arguments for its origination, one finds that al-Junayd's statement vividly captures Ibn Taymiyya's epistemology on God's essence and attributes vis-à-vis the human soul. In this sense, the soul's origination entails the affirmation of God's essence and of God's attributes as eternal and unidentifiable with the human being's essence and soul. Naturally, this is the purpose of Islamic monotheism (tawhìd), i.e., single God out as the one and only divinity, unparalleled in nature. One is uncertain whether Francis Cooke had in mind this interpretation when he spoke of Islam's "genius for theological concretion," or by this description he only meant that Ibn al-Qayyim's eschatology was suggestive of materialism in the postmortem and the afterlife's events. Either way, this sharp insight resulted from his reflection upon the work of Ibn Taymiyya's disciple.

Just as Ibn Taymiyya meant to uphold God's essence, he also wanted to uphold human morals by rejecting notions of the soul's eternity and identification with God's essence. I. R. Al Fārūqi argues (italics mine): "The Christian doctrine of the incarnation through its idea of a God immanent in the flesh and hence in nature, eased the transfer from the Semitic notion of a transcendent God who is the absolute standard of beauty, truth and morality, to man as absolute standard." ${ }^{92}$ This analysis dovetails with the thrust of Ibn Taymiyya's main argument in Khalq.

\footnotetext{
90 See Khalq, MF, 4:220 on al-Junayd's comradeship.

91 Shādhilī, 158-60.

92 Ismā'īl Rājī Al Fārūqī, Islam: Religion, Practice, Culture \& World Order, ed. Imtiyaz Yusuf (London and Washington: The International Institute of Islamic Thought, 2012), 87.
} 
The second conclusion presents general observations about the methodology of Shaykh al-Islām, a pragmatic theologian who was concerned with maintaining a pristine version of Islamic belief and praxis. In his approach to the human soul, he essentially focuses upon God as well as the soul's provenance and destination. Hence more theological, spiritual and linguistic treatments emerge from his corpus than do philosophical treatments of the problem of the soul's eternity, despite his appropriation of the philosophers' language. As a theologian, he stands midway between the reductionists and the assimilationists in terms of God's attributes. As a spiritualist, his position is midway between those of the incarnationists and the naturalists concerning human soul. As a linguist, he works across Islamic disciplines.

Despite his loyalty to Hanbalism, Ibn Taymiyya is not indiscriminate. Ibn Hanbal remains a major source of inspiration for him, and yet Ibn Taymiyya does not hesitate to criticize Ibn al-Jawzī, Ibn 'Aqīl, and Ibn Ḥāmid. Nor is he totally antagonistic to those who hold opposite views. Known for his attacks on al-Ghazāli, he nevertheless employs some of the latter's arguments to further his own positions. He is iconoclastic of al-Hallāj, but appreciates some of his views. The diversity of voices cited in his works to support or challenge his own argument indicates his tolerance, which is sometimes blemished with harshness.

For Ibn Taymiyya, scripturalism represents the solution to intellectual problems lying outside the scope of certain human knowledge. However, his scripturalism is fully informed with the legacy of scholarship. Hence, he utilizes the most significant works written by earlier Islamic scholars. Taking nothing at face value, he engages in critical and even controversial disputes, for which he musters his intellectual capability in order to make full use of his familiarity with the tools of the craft. His scholarship is amazingly erudite and precise, and those who study him often find themselves hard pressed to choose, verify, and incorporate his ideas synthetically. 


\section{Translation of Khalq}

[216] Shaykh al-Islām Abū l-'Abbās b. Taymiyya—may God sanctify his soulwas asked about the spirit (rüh): Is it eternal (qadìm) or created (makhlüq)? Would someone who speaks of its eternity be innovating or not? What do the People of the Sunna say about it? What is the meaning of the saying of God, Mighty and Majestic: "Say, "The spirit ( $r u \bar{h})$ is from the affair (amr) of my Lord"'? [Q17:85]93 Is what is entrusted to God Most High a matter of its essence, its attributes, or both together? Expound this based on the Book and the Sunna.

[Ibn Taymiyya] — may God be pleased with him—answered:

Praise be to God, the Lord of the worlds. The spirit of the Adamic [being] is created and originated. There is unanimity among the ancients of the community, its imāms, and the rest of the People of the Sunna about this. More than one of the leading scholars (imäms) of the Muslims reported the consensus of the ulema on [the spirit] being created, such as Muhammad b. Nașr al-Marwazī, ${ }^{94}$ the famous imām who was the most knowledgeable of the people of his time about consensus and divergence, or [was] one of the most knowledgeable of them. ${ }^{95}$ Likewise, Abu Muhammad b. Qutayba ${ }^{96}$ said in Kitāb al-lafz,${ }^{97}$ when he talked about the creation of the spirit: "The persons (nasma) are the spirits." He [also] said: "There is a consensus of the people that God is the creator of the body [217] and the originator of the person, namely, the creator of the spirit." ${ }^{\prime 8}$ In his answer to this question, Throughout part II, nafs is translated as "soul" and ruh as "spirit".

94 Al-Marwazī, Muhammad b. Nașr (d. Samarqand, 294/906), a specialist in hadīth and fiqh. See Khayr al-Dīn al-Ziriklī (d. 1396/1976), al-A'lām, 8 vols. (Beirut: Dār al-'Ilm lil-Malāyīn, 2002), 7:125 [hereinafter A'lām].

95 Al-Marwazi reports the consensus of the Salaf that the soul and the body are subject to bliss and torment after death. See Janāiz, FK, 5:364-65.

96 Ibn Qutayba al-Dīnawarī, Muhammad b. Muslim (d. Baghdad, 276/889), was a versatile scholar and philologist who favored Ibn Hanbal, although he himself was probably a Mālikī. See al-Dhahabī, Siyar a lām al-nubalā', ed. Shu'ayb al-Arnā'ūṭ et al. 25 vols. (Damascus: Mu'assasat al-Risāla, 1405/1985),13:296302 [hereinafter Siyar]; al-Ziriklī, A 'lām, 4:137; G. Lecomte, "Ibn Kutayba," EI² 3:844-47. Franz Rosenthal, "Ebn Qotayba, Marwazī Mohammad “Abd al-Allāh,” in EIR.

97 Al-Lafẓ: al-luqaț $\mathbf{F}$

98 Ibn Qutayba: "I was informed that some people tend to [say] that the spirit of the human being is uncreated; they prove this by God's saying about Adam, 'And I have breathed into him of My spirit' (Q15:29). This is [typical of] Christianity and [of] the saying about divinity (lāhūt) and humanity (nāsūt). Al-Nābighat al-Ja'dī (d. 50/670) said [in poetry], 'From a sperm-drop determined by its Determiner/He creates from it humans (insān) and persons.' The persons are the spirits" (al-Ikhtilāf fi l-lafz wa l-radd 'alā l-jahmiyya wa l-mushabbiha, ed. 'Umar Maḥmūd Abū 'Umar (Riyadh: Dār al-Rāya, 1412/1991), 65-66). 
Abū Ishāa b. Shāqlā99 stated: "You asked-may God have mercy upon you—about the spirit, whether it is created or uncreated." He replied: "This is among the things which are not doubted by anyone who has been guided to what is correct," until he said, "And the spirit is among the created things." Groups of the greatest ulema and shaykhs have spoken about this question and refuted those who claim that [the spirit] is uncreated.

Al-Hāfiz Abū 'Abd Allāh b. Manda ${ }^{100}$ composed a large book on the spirit and the soul in which he mentioned plenty of hadiths and traditions. ${ }^{101}$ [Similarly,] Imām Muhammad b. Nașr al-Marwazī, Shaykh Abū Ya'qūb al-Kharrāz ${ }^{102}$ and Abū Ya'qūb al-Nahrajūrī, ${ }^{103}$ al-Qāḍi Abū Ya'lā, ${ }^{104}$ and others did the same thing before him. The great imāms also wrote about this and severely reproached those who spoke of [uncreatedness] as regards the spirit of Jesus Son of Mary, not to mention as regards the spirit of other people, as mentioned by Ahmad ${ }^{105}$ in his book ${ }^{106}$ on refuting the heretics (zindī ) and the Jahmīs. ${ }^{107}$

99 Ibn Shāqlā, Ibrāhīm b. Aḥmad al-Bazzāz (d. 369/979), a leading Ḥanbalī jurist. Al-Khațīb al-Baghdādī (d. 463/1072), Tārīkh Baghdād, ed. Bashshār Ma'rūf, 16 vols. (Beirut: Dār al-Gharb al-Islāmī, 1422/2002), 6:507

100 Ibn Manda, Muhammad b. Ishạa (d. 395/1005), ḥadīth specialist. Al-Dhahabī, Siyar, 17:28-43.

101 This book appears to be lost. It is not listed in Fuat Sezgin, Geschichte des arabischen Schrifttums (Leiden: E. J. Brill, 1967), 1:214-15. Also, 'Alī al-Faqīhī, the editor of Ibn Manda's Kitāb al-tawhid wa-ma'rifat asmā’ Allāh wa-ṣifātih 'alā l-ittifāq wa l-tafarrud, 3 vols. (Al-Madīna: Mațābi‘ al-Jāmi‘a al-Islāmiyya, 1413/1992) could not find Ibn Manda's book on the soul; see esp. 1:25. Ibn al-Qayyim records part from its introduction, which, I believe, inspired Ibn Taymiyya's structuring of Khalq. See Rüh, 2:421. Likewise, Ibn al-Qayyim quotes Ibn Manda's citation of anonymous typologies of the soul that correspond to some of Ibn Taymiyya's arguments in his Khalq and other works. See Ruh, 2:618-19.

102 Al-Kharrāz, Ahmad b. 'Īsā (d. 286/899), a mystic of the school of Baghdad. His correct nickname is Abū Sa'īd, as later seen in Khalq, MF, 4:220. Wilferd Madelung, "al-Kharrāz," $E I^{2}, 4: 1083$.

103 Al-Nahrajūrī, Abū Ya'qūb (d. Makkah, 330/941), a sufi scholar originally from Nahr Jūr (close to Ahwāz) who traveled to Hijāz. Al-Ziriklī, A'lām, 1:296.

104 Ibn al-Farrā', Abū Ya 'lā (d. 458/1066), an erudite Ḥanbalī scholar of Baghdād. Henri Laoust, "Ibn alFarrā'," $E I^{2}, 3: 765$.

105 Ahmad b. Hanbal (d. 241/855), a celebrated theologian, jurist, traditionist, and founder of Hanbalism. Henri Laoust, "Ahmad b. Hanbal," EI², 1:272.

106 Aḥmad b. Hanbal, al-Radd 'alā al-zanādiqa wa l-jahmiyya fīmā shakkū fìhī min mutashābih al-Qur'ān wa ta'wwalūhū 'alā ghayri ta'wīlih, ed. Daghash al-'Ajamī (Kuwait: Ghirās, 1426/2005) [hereinafter Radd/ 'Ajamī; sigle R1], 124. For an earlier, less standard edition, see Ahmad b. Hanbal, al-Radd 'alā al-jahmiyya wa l-zanādiqa fìmā shakkū fỉhī min mutashābih al-Qur'ān wa ta'wwalūhū 'alā ghayri ta'wīlih, ed. Șabrī Shāhīn (Riyadh: Dār al-Thabāt, 1424/2003) [hereinafter Radd/Shāhīn; sigle R2]. For the authenticity of Radd, see Saud AlSharhan, "Early Muslim Traditionalism: A Critical Study of the Works and Political Theology of Ahmad Ibn Hanbal," (PhD diss., University of Exeter, 2011), 48-53; Jon Hoover, "Hanbali Theology," in The Oxford Handbook of Islamic Theology, ed. Sabine Schmidtke (2014): accessed on June 10, 2015, DOI: 10.1093/oxfordhb/9780199696703.013.014.

107 A sect founded by Jahm b. Șafwān, whose adherents believed in fatalism and the creation of the Qur'ān. W. M. Watt, "Djahmiyya," $E I^{2}, 2: 388$. 
At the beginning [of this book, Ahmad] said: ${ }^{108}$

Praise be to God Who commissioned in every time, when there were no messengers, ${ }^{109}$ a remainder of the people of knowledge to call those who were going astray to guidance and to have patience with their abuse, revive the dead by means of the Book of God, and give vision to the people of blindness by means of God's light. How many people killed by Iblis did they revive! How many people who had strayed and become lost did they guide! How beautiful was their impact on people, and [how] ugly the impact of people on them! They drove away from God's Book the distortion (tahriff) of the exaggerators, the [undue] assumptions of the falsifiers, and the interpretations of the ignorant, ${ }^{110}$ those who had tied the banners of innovation ${ }^{111}$ and untied the shackles of dissension. ${ }^{112}$ Those were diverging on the Book, opposed to the Book, and unanimous on opposing the Book! They spoke of God, about God, and about the Book of [218] God without knowledge. They spoke an ambiguous language and deceived the ignorant people by confusing them. Therefore, we seek refuge in God from the dissension of the misleaders. ${ }^{113}$

[Ibn Hanbal] also talked about what was said to be contradictory in the Qur'ān, until he said:

Likewise, al-Jahm ${ }^{114}$ and his party invited people to what is ambiguous in the Qurān and hadith and misled many people. Among the things that reached us concerning alJahm, the enemy of God, is that he was from the inhabitants of Khurāsān, [particularly] from the inhabitants of al-Tirmidh. He was a man of arguments and [uninformed] discourse (kalām). ${ }^{115}$ Most of what he was speaking about (kalām) had to do with God. He met people from the associators called "the Sumanīs." ${ }^{116}$ They recognized al-Jahm and said to him, "We will speak to you, and if our argument prevails over you, you will enter our religion. And if your argument prevails over us, we will enter your religion." Among the things they spoke about with al-Jahm were:

— Do you not claim to have a God?

— Yes, al-Jahm said.

See Ibn Ḥanbal, Radd/Shāhīn, 55-57, 92-95, 125-26; idem, Radd/'Ajamī, 170-74, 196-99, $249-52$.

Fatra is the period separating two prophets or two successive messengers. C. Pellat, "Fatra," EI ${ }^{2}, 2: 865$. Abū l-Fidā' Ibn Kathīr (d. 774/1372), Jāmi‘ al-masānīd wa l-sunnan al-hādī li-aqwam sanan, ed. 'Abd al-Malik al-Deheish, 12 vols. (Beirut: Dār Khiḍr, 1419/1998), 1:68.

1 Non-lit. "those who initiated innovations [in religion]."

Non-lit. "and started/sparked dissension." Ibn Hanbal, Radd/Shāhīn, 55-57; idem, Radd/'Ajamī, 170-74.

4 Jahm b. Șafwān (executed in 128/746), the eponym of Jahmiyya, an early theologian who argued for God's existence against the Indian Sumanī sect. W. M. Watt, "Djahm b. Șafwān," EI2, 2:388.

5 L. Gardet, "Kalām," EI2, 4:468.

6 Buddhists. See G. Monnot, “Sumanīs,” EI², 9:869. 
- Have you seen your God?

- No.

— Have you heard Him speak?

- No.

- Have you smelled an odor of Him?

- No.

— Have you found for Him a place where He could be felt?

- No.

- So, what makes you know that He is a God?

Hence, al-Jahm was confounded and did not know whom to worship for forty days. ${ }^{117}$ Then he thought of an argument similar to that of the Nazarene ${ }^{118}$ heretics, who claim that the spirit being in Jesus was the spirit of God, from His essence. [Accordingly,] if He wants to bring about a matter, He enters into some of His creatures and speaks through their tongues to command what He wills and to forbid what He wills, being a spirit concealed from visions. Al-Jahm thus thought of an argument similar to this one and related it to the Sumani:

- Do you not claim that there is a spirit in you?

- Yes, the Sumanī replied.

- Have you seen your spirit?

- No.

- Have you heard [219] it speaking?

- No.

- Have you found it in a place in which it can be felt?

- No.

- So is God: He is not seen to have a face; He is not heard to have a voice; He is not smelled to have an odor. He is concealed from visions and is not in a particular place. ${ }^{119}$

Imām Aḥmad spoke about the Qur'ān, the seeing [of God], etc. until he said:

Moreover, al-Jahm claimed something [else] ${ }^{120}$ : "We have found in the Book of God a verse proving that the Qur'ān is created.” We asked: “Which verse?” He replied: “[This]

117 Ibn Taymiyya comments on this part of Ibn Hanbal's quotation elsewhere, intimating that al-Jahm had no proper understanding of Islam and lacked righteousness and scruples. Nevertheless, he argued with Indian philosophers (i.e., the Sumanis) who believed only in perceivable things. As a result, he doubted his faith and, not knowing his Lord, did not observe prayers for forty days, (Țawäiff, FK, 6:361-62).

118 See Q. M. Fiey, "Nașāara," EI $I^{2}$, 7:970. The Nașārā mentioned in the Qư'ān were the Nazoraeans who

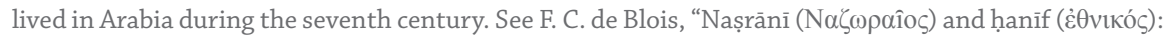
Studies on the Religious Vocabulary of Christianity and of Islam," Bulletin of the School of Oriental and African Studies 65.1 (2002): 1-17.

119 Also mentioned in Manțiqiyyinn, 329; Țawä̉if, FK, 6:360-64; Talbiss, 2:329-30; Dar', 5:165-68. Cf. Ibn Ḥanbal, Radd/Shāhīn, 92-95; idem, Radd/'Ajamī, 196-99.

120 Ibn Ḥanbal, Radd/Shāhīn, 125-6; Radd/'Ajamī, 249-52. 
saying of God 'Surely, the Messiah, Jesus, Son of Mary, was but the Messenger of God and His word, which He cast forth to Mary and a spirit from Him..$^{[\text {Q4:171] }}$ Now, Jesus is created." We thus stated: “God has prevented you from understanding the Qur'ān. There are terms applying to Jesus that do not apply to the Qur'ān. Indeed, to him apply the ex-

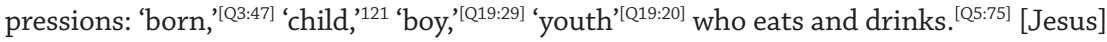
is also addressed with commands and prohibitions and is subject to the promise and the threat. Furthermore, he is among the descendants of Noah and of Abraham. ${ }^{122}$ Now, it is not lawful for us to say about the Qur'ān what we [so] say about Jesus. Have you heard God say about the Qứa àn what He said about Jesus? But what is meant in God's saying 'Indeed, the Messiah, Jesus, Son of Mary, was but a messenger of God and His word that He cast forth to Mary ${ }^{\text {[Q4:171] }}$ is the word which He conveyed to Mary when He said to him 'Be!' Indeed, Jesus came into being by the 'Be!' and Jesus is not the 'Be!' but by the 'Be!' he came into being. The 'Be!' is a saying from God, and the 'Be!' is not created."

Both the Nazarenes and Jahmis have spoken falsely about God in the matter of Jesus, for the Jahmis say, "Jesus is the spirit of God and His Word, but the Word is created."123 The Nazarenes say that [220] Jesus is the spirit of God from the essence of God, and the Word of God from the essence of God, ${ }^{124}$ as it is said that this piece of cloth is from this garment. As for us, we say that Jesus was by the word and was not himself the Word.

As for God's saying "a spirit from Him," He says that it is by His command that the spirit was from ${ }^{125} \mathrm{Him}$, just as He says: "He has made of service to you whatever is in the skies and whatever is on Earth; everything being from Him." ${ }^{[045: 11]}$ He means: "from His command," and the explanation of "the Spirit of God" [only carries the meaning] that it is a spirit by the word of God, which God created, as it is said "servant of God" and "sky of God."126

Thus, Imām Ahmad mentioned that the Nazarene heretics are those who hold that Jesus' spirit is from God's essence. He also explained that relating the spirit to God is a relation of ownership and creation, like your saying "the servant of God" and "the sky of God," which is not the relation of an attribute to the being thereby

121 The Qur'ān does not describe Jesus as "țif", but as "walad (Ibn Hanbal: mawlūd) [Q3:47]”, "ṣabiyy/ young boy [Q19:29]", and "ghulām/youth [Q19:20]."

122 Ibn Taymiyya: "All [people] are from the progeny of Noah and from the progeny of Adam. The Children of Israel, their Jews and gentiles, are from the progeny of Abraham, Isaac, and Jacob" (Minhāj, 4:6566).

123 Translated as "because he is the created word" in Thomas Michel, A Muslim Theologian's Response to Christianity: Ibn Taymiyya's Al-Jawab Al-Sahih (New York: Caravan Books, 1984), 185.

124 Translated as "the spirit of God is of the essence of God, and the word of God is of the essence of God" in ibid, 185.

125 minhu: fỉhi $\mathbf{F}$

126 The translation from "But what is meant ..." to the end of the next two paragraphs is adapted from Michel, Response to Christianity, 185. 
described. How much more so are the spirits of the rest of the Adamic beings? He further explained that those heretics [who believe in] God's indwelling (hulūl) ${ }^{127}$ assert that when God wants to bring about a matter, He enters into some of His creatures.

Shaykh Abū Sa'ìd al-Kharrāz, one of the greatest of all master shaykhs and a comrade of al-Junayd, ${ }^{128}$ said [the following] in what he had written ${ }^{129}$ about the spirit being created, furnishing, among others, these arguments:

If [the spirit] were not created, it would not have acknowledged the [divine] lordship. When God took the covenant ${ }^{130}$ while they were spirits in corporeal shapes like atoms, He asked them: "Am I not your Lord?" They replied: "Yes, we have testified."[07:172] $\mathrm{He}$ had addressed the spirit [together] with the body. [Now], is a lord, indeed, [a lord] except [to] those things [that are] subjected [to Him]? If the [spirit] were not created, the Nazarenes would not have been blamed for worshipping Jesus ${ }^{[05: 73-76]}$ or when they said that he is the son of God ${ }^{[09: 30]}$ and that he is God. ${ }^{[05: 72]}$ [221] Also, if the spirit were not created, it would not enter the Fire. Also, if it were not created, it would not be veiled from God, ${ }^{[Q 83: 15]}$ nor would it be concealed in the body, nor would the angel of death ${ }^{[\mathrm{Q} 32: 11]}$ seize it, ${ }^{131}$ nor would it be a form to be described. ${ }^{\left[{ }^{[40: 64]}\right.}$ Moreover, if it were not created, it would neither be questioned nor tormented. It would neither worship, nor fear, nor hope. It is also because the spirits of the believers glitter, whereas the spirits of the unbelievers are [as] black as charcoal. The Prophet, God bless him and grant him peace, said: "The spirits of the martyrs are in the crops of green birds pasturing in the Garden and lodging in the courtyard of the Throne, ${ }^{132}$ whereas the spirits of unbelievers are in Barahūt." 133

See L. Massignon-[G. Anawati], “Hulūl," $E I^{2}, 3: 570$.

128 Al-Junayd, Abū l-Qāsim (d. 298/910), a celebrated orthodox mystic. A. J. Arberry, "al-Djunayd," $E I^{2}$, 2:600.

129 Al-Kharrāz is said to have written Kitāb al-șiyām; see Ismā'îl al-Baghdādī (d. 1339/1920), Hadiyyat al'ārifin asmä' al-mu'allifin wa āthār al-mușannifīn, 2 vols. (Istanbul: Wakālat al-Ma'ārif al-Jalīla, 1951), 1:55. It could be Kitāb al-șidq, ed. A. J. Arberry (Oxford University Press, 1937), who said this is the only surviving work of al-Kharrāz. Kitāb al-șiḍq contains no mention of al-Kharrāz's argument about the spirit's createdness. However, a tradition cited in this book does indicate that God had breathed into Adam from His own spirit before He created him.

130 Ibn Hanbal, al-Musnad, ed. Shu'ayb al-Arnā'ūṭ et al., 50 vols. (Damascus: Mu'ssasat al-Risāla, 1422/2001), (hadìth no. 2455), 4:267 [hereinafter Musnad].

131 qabaḍahā: malakahā $\mathbf{F}$

132 Muslim ibn al-Hajjāj (d. 261/874), Șaḥịh Muslim, ed. Muhammad F. 'Abd al-Bāqī, 5 vols. (Cairo: Dār Ihyā’ al-Kubub al-'Arabiyya. Repr., Dār al-Ḥadìth, 1412/1991), (ḥadīth no. 1887), 3:1502. [hereinafter Șahīh]

133 G. Rentz, "Barhūt," EI², 1:1045. 
Shaykh Abū Ya'qūb al-Nahrajūrī said:

These spirits are, from God's command, created. God created them from the king$\operatorname{dom}^{[07: 185]}$ as He created Adam from dust. ${ }^{[Q 3: 59]}$ Any slave who relates his spirit to God's essence is led to reductionism ( $\left.t a^{\prime} t \underline{i} l\right) .{ }^{134}$ Those who relate the spirits to God's essence uphold [God's] indwelling and thus end up in antinomianism. ${ }^{135}$ They say: "When our spirits are purified from the turbidities of our souls, we have become joined [to God], have become free, and have been discharged from servitude. Thus, everything from the pleasures including women, possessions, and other things has been permitted to us." ${ }^{136}$ They are the heretics of this community.

[Al-Nahrajūrī] mentioned several of their statements as well as those of [other] heretics.

Those who advocate the spirit's eternity are of two categories. One category includes the Sabian philosophers, who say that the spirit is eternal and pre-eternal, but not from [222] God's essence, and who say the same thing about intellects and celestial souls. People of [different] religions who join them claim that these spirits are the angels. The second category includes the heretics of this community and its straying people from the Sufis, Kalām theologians, and traditionists. They claim that the spirit is from God's essence. These are more evil in what they say than those who belong to the first category, [because] they maintain that the Adamic being [consists of] two halves: divinity (his spirit) and humanity (his body). [Thus] one half of him is a lord, and the other half is a slave. Now, God declared the Nazarenes unbelievers because they said something similar about the Messiah. So how about those who generalize this about everyone, even about Pharaoh, Hāmān, and Qārūn? ${ }^{137}$

Everything that proves that man is a slave [of God], created and subjected [to Him], and that God is his lord, creator, owner, and deity, also proves that his spirit is created. Indeed, man consists of the body and the spirit together. He is, rather, more distinguished by the spirit than by the body. The body is only a mount (mați-

134 Joseph van Ess, “Tashbīh wa-Tanzīh,” $E I^{2}, 10: 341$.

135 See Ahmet Karamustafa, "Antinomian Sufis," in The Cambridge Companion to Sufism, ed. Lloyd Ridgeon (New York: Cambridge University Press, 2015), 101-24.

136 A reference to the servitude-freedom and permission-antinomianism tropes are found in Abū Nașr al-Sarrāj (d. 378/988), Kitāb al-luma', ed. 'Abd al-Halīm Maḥmūd and Ṭāhā 'Abd al-Bāqī Surūr (Cairo: Dār al-Kutub al-Ḥadītha and Baghdad: Maktabat al-Muthannā, 1380/1960), 531-32, 538ff. Al-Sarrāj concludes his book by commenting on [Q17:85]: "The people of the truth and correctness, I believeand God knows best-, maintain that all spirits are created, being a command from the command of God Most High. They have no relation with God Most High, nor are they attributed to Him, except that they are from His kingdom, at His order, and in His grip..." at p. 555. Although al-Nahrajūrī is one of the sources of Kitāb al-luma', it is uncertain if he is being summarized and referred to here. 
yya) for the spirit, as Abū al-Dardā'138 said: "Indeed, my body is my mount. If I am gentle with it, it will deliver me [to my destination]. However, if I am not gentle with it, it will not deliver me." ${ }^{39}$ Ibn Manda and others also narrated from Ibn 'Abbās ${ }^{140}$ [that] he said:

Creatures will not stop disputing on the Day of Resurrection. Even the spirit and the body will dispute. The spirit will say to the body: "It was you who committed the sins." And the body will say to the spirit: "It was you who commanded me." Hence, God will send an angel to judge between them. [The angel] will then say: "You are, in parable, like a crippled [person] and a blind [person] who entered an orchard together. The crippled one saw fruits hanging therein, so he said to the blind one: 'I see fruits but [223] I cannot rise to [get] them.' The blind one replied: 'I can reach out to them, but I cannot see them.' The crippled one said to him: 'Come and carry me so that I will pick them.' So he carried him and [the crippled one] gave him instructions to walk him where he wanted until he picked the fruits. The angel asked: 'Which of them deserves the punishment?' They answered: 'Both of them.' Therefore, the angel said: 'Likewise you."'

Also, a plethora of hadiths was narrated from the Prophet, God bless him and grant him peace, [indicating] that the spirits are made to die, are subject to bliss and torment, and are told:

"Get out, O you good spirit, which was in the good body. Get out, O you wicked spirit, which was in the wicked body." The former is told: "Rejoice at [the good news of having] relief and soothing comfort." ${ }^{[05: 89]}$ However, the latter is told: "Rejoice at [the good news of having] scalding water, constantly overflowing pus, and other torments of like kind paired together."[038:57-58] Moreover, the spirits of the believers ascend to the sky, whereas the doors of the sky are not opened for the souls of the unbelievers. ${ }^{141}$

In Șaḥịh Muslim, [it is reported] from 'Abd Allāh b. Shaqī ${ }^{142}$ from Abū Hurayra, ${ }^{143}$ may God be pleased with him, [the Prophet] said:

138 Abū l-Dardā', Mālik al-Anșārī (d. 32/652), a Companion of Prophet Muhamammad. A. Jeffery, "Abu l-Dardā'," $E I^{2}, 1: 113$.

139 Rather, it was "Umar b. 'Abd al-'Azizz (d. 101/720) who said that to his son, speaking of his "soul" instead of his "body." Immediately after his inauguration, his son urged him to expedite justice for those who had been oppressed by the former regime. He replied: "Dear son, my soul is my mount, so if I am not gentle with it, it will not deliver me.” Ibn Hanbal, al-Zuhd, ed. Muhammad Shāhīn (Beirut: Dār al-Kubub al-'Tlmiyya, 1420/1999), (hadith no. 1700), 238.

140 Ibn 'Abbās (d. 58/686), father of Qur'ānic exegesis. L. Veccia Vaglieri, “'Abd Allāh b. al-'Abbās,” EI², 1:40.

141 Ibn al-Mubārak (d. 181/797), al-Zuhd wa l-raqāiqq, ed. Habīb al-Raḥmān al-A‘ẓamī (Beirut: Dār al-Kutub al-'Ilmiyya, 1400/1980) (hadith no. 1223), 1:434.

142 'Abd Allāh b. Shaqīq al-'Uqaylì (d. 108/726), a ḥadīth transmitter based in Bașra. Al-Dhahabī, Tārīkh, 3:79.

143 Abū Hurayra, 'Abd al-Raḥmān b. Șakhr (d. 59/679), a great narrator of Prophetic traditions. J. Robson, “Abū Hurayra," EI $I^{2}, 1: 129$. 
When a believer's spirit leaves [the body], two angels receive it and ascend with it. (Hammād ${ }^{144}$ said that [the Prophet] spoke of the goodness of its smell and mentioned musk.) [The Prophet] stated: "The dwellers of the Garden, therefore, shall say: '[That is] a good spirit coming from the direction of Earth. May God bless you ${ }^{145}$ and the body that animated you!' Hence, [the spirit] will be taken to its Lord, who will then tell [the angel]: 'Take it until the end of the term."'146 [The Prophet] said: "Concerning the unbeliever, when his spirit leaves [the body]" (Hammād said that [the Prophet] spoke of its foulness and mentioned a curse) "the dwellers of the Garden shall say: '[That is] a wicked spirit coming from the direction of Earth.' He stated: "It shall be told: 'Take it to end of the term."' ${ }^{147}$ Abu Hurayra, may God be pleased with him, said that when God's Messenger, God bless him and grant him peace, mentioned the foulness, he covered his nose with the mantle that he was wearing. ${ }^{148}$ [224]

Also, in the authentic Hadith of Ascension, ${ }^{149}$ [it is narrated that] the Prophet, God bless him and grant him peace, saw Adam and the spirits of his children on his right and his left. God's Messenger, God bless him and grant him peace, said:

When we ascended to the sky, there was a man with persons on his right and persons on his left. [The Prophet] said [that] [Adam] laughed when he looked to his right and wept when he looked to his left. He said: "Welcome to the righteous Prophet and the righteous son." [The Prophet] stated: I said: "O Gabriel, who is this?" He replied: "This is Adam, God bless him and grant him peace. Those persons on his right and left are the spirits of his children. The people on his right are the people of the Garden, and the people on his left are the people of the Fire. Thus he laughs when he looks to his right and weeps when he looks to his left." 150

It has been also established that the spirits of believers, martyrs, and others are in the Garden. Imām Aḥmad said in a report [narrated] by Hanbal:151

144 Hammād b. Zayd (d. Bașra, 179/795), a leading ḥadīth transmitter. Al-Ziriklī, Alām, 2:271.

145 There is a sudden discursive transition from the third person to the second person (iltifät) for the special prayers being invoked on the good spirit. See 'Alī al-Qārī (d. 1014/1606), Mirqāt al-mafātīh sharh mishkāt al-mașābīh, ed. Șidqī al-'Aț̣ār. 11 vols. (Beirut: Dār al-Fikr, 1414/1994) (hadīth no. 1628), 4:98.

146 "To the end of the term," namely, to Sidrat al-Muntahā (the Lote Tree of the Utmost Boundary). See Q53:13. See also 'Abd al-Bāqī’s footnote in Șahīh, 4:2202.

147 "To the end of the term," namely, to Sijjin (the destination of the libertine). See Q83:6-8. See also 'Abd al-Bāqī's footnote in Șahīh, 4:2202.

148 Muslim, Șahīh, (hadìth no. 2872), 4:2202.

149 On misappropriating this tradition, see Salaf, MF, 4:62.

150 Al-Bukhārī (d. 256/870), al-Jāmi al-Ṣaḥiḥ, 9 vols. (Cairo: Būlāq, 1311/1893), (hadīth no. 3342), 4:135 [hereinafter Sahīh]]; Muslim, Șahīh, (hadìth no. 263), 1:148.

151 Ḥanbal b. Ishạāq (d. 273/886), a cousin of Aḥmad b. Hanbal. Al-Ziriklī, A'tām, 2:286. 
The spirits of the unbelievers are in the Fire, and the spirits of the believers are in the Garden, while the bodies are in the world. God torments whomever He wills and has mercy by means of His forgiveness on whomever He wills. ${ }^{152}$

'Abd Allāh b. Aḥmad'153 said:

I asked my father: "Are the spirits of the deceased in the spaces of their tombs or in the crops of birds, or do they die as the bodies die?" He replied that it was narrated from the Prophet, God bless him and grant him peace, that he said, "The spirit of the believer, when he dies, [becomes] a bird that eats from the trees of the Garden until God returns it to his body on the day He resurrects him." ${ }^{154}$

Moreover, it was narrated from 'Abd Allāh b. 'Amr ${ }^{155}$ that he said: "The spirits of believers are in the bellies of green birds like starlings [in the Garden], where they get to know each other and are provided with its fruits." Some people also said: "The spirits of martyrs are in the bellies of green birds that perch in lamps in the Garden hanging from the Throne."

Also, Muslim narrated in his Șah̄ịh from Masrūq ${ }^{156}$ that he said:

We asked 'Abd Allāh, i.e., Ibn [225] Ma'sūd, ${ }^{157}$ about this verse: "And do not ever consider the ones who have been killed in the path of God [as] dead; no indeed, they are alive with their Lord, [by Him] provided." He said, "Indeed, we asked the Messenger of God, God bless him and grant him peace, about this and he replied: "Their spirits are in the bellies of green birds for which there are lamps suspended to the Throne. They pasture where they want in the Garden, and then they perch in those lamps. Your Lord looked at them once and asked: "Do you desire anything?" They answered: "What might we desire when we pasture in the Garden where we want?" [God] did that to them three times. When they saw that they would not be left without being asked, they said, "O Lord, we want that you return our spirits to our bodies so that we will be killed in your path once again." When He saw that they had no need [for anything], they were left [alone]."'158

152 This citation is located neither in the Musnad nor in other hadith collections.

153 'Abd Allāh b. Ahmab b. Hanbal (d. 290/903).

154 Ibn Māja (d. 273/887), al-Sunan, ed. Muhammad F. 'Abd al-Bāqī, 2 vols. (Cairo: Dār Iḥyā' al-Kutub al'Arabiyya, n.d.), (hadith no. 4271), 2:1428 [sigle: J].

155 'Abd Allāh b. 'Amr b. al-'Ạṣ (d. 65/684), a scribe of the Prophet and a noted observant of Islam. AlZiriklī, A'tām, 4:111-12.

156 Al-Hamdānī, Masrūq b. al-Ajda' (d. 63/683), lived in Kūfa and witnessed the wars of 'Alī (d. 40/661). Al-Ziriklī, A'tām, 7:215.

157 Ibn Mas'ūd, 'Abd Allāh (d. 32/653), one of the Prophet's Companions and the first to read the Qur'ān publicly in Makkah. See al-Ziriklī, A'lām, 4:137; J. Vadet, "Ibn Mas'ūd," EI², 3:873.

158 Muslim, Șahìh, (hadìth no. 1887), 3:1502. 
God Most High said, "O soul that is serene. Return to your Lord well-pleased and pleasing [to Him]! So enter among My servants! And enter My Garden!"[089:27-30] He thus told it to return to its Lord, to enter among His servants, and to enter His Garden. This is an explicit [statement] that the [soul] is subjected to a Lord. The soul here is the spirit that is seized at death. However, its attributes do vary as [indicated] in this authentic hadith. When [the Companions] missed the dawn prayer by oversleeping on a journey, the Prophet, God bless him and grant him peace, said: "Indeed, God seized your spirits ${ }^{159}$ when ${ }^{160} \mathrm{He}$ willed and returned them when ${ }^{161}$ He willed." ${ }^{162}$ In [another] narration: "He seized our souls where He willed." ${ }^{163}$ The Most High also proclaimed: "God takes the souls at the time of their death, and those that do not die [He takes] during their sleep. Then He keeps those for which He has decreed death and releases the others for a specified term." ${ }^{[039: 42]}$ What is seized and restored is the spirit, as [indicated] in the Sahịih of Muslim, from Umm Salama, ${ }^{164}$ who said:

The Messenger of God, God bless him and grant him peace, entered [the place of] Abū Salama ${ }^{165}$ [who had died] and his eyes were still open. So he closed them and said: "When the spirit is seized, vision follows it." Some people from [Abū Salama's] family cried loudly. Hence, [the Prophet] stated: [226] "Only invoke good upon yourselves, because the angels say 'Amen' upon anything you say." Then he stated: "O God, forgive Abū Salama and elevate his degree among the well-guided. Take care of his family among those who survive [him]. O Lord of the worlds, forgive us and him, provide ample space for him in his grave, and give him light therein." ${ }^{166}$

Muslim also narrated from Abū Hurayra who said that the Messenger of God, may God bless him and grant him peace, asked: "Do you not see that when a human

159 arwāḥakum: arwāḥānā $\mathbf{F}$.

160 hīna: haythu $\mathbf{F}$.

161 hìna: haythu $\mathbf{F}$.

162 Al-Bukhārī, Șahīh, (hadīth no. 7471), 9:139 and (hadìth no. 595), 1:122. Commenting on hadith no. 595, Ibn Rajab al-Hanbali (d. 795/1392 or 1393) says: "It includes a proof for those who do not differentiate between the spirit and the soul, for [the Prophet] endorsed Bilāl's saying [in hadìth no. 680 in Sahīh Muslim] that Allāh took their souls by saying that Allāh seized [your] spirits." See Fath al-Bārī sharḥ șaḥị̣ al-Bukhārī, ed. Maḥmūd 'Abd al-Maqșūd et al., 10 vols. (Al-Madīna: Maktabat alGhurabā' al-Athariyya, 1416/1996), 5:104.

163 I could not identify the source of this citation.

164 Umm Salama, Hind bt. Suhayl al-Makhzūmiyya (d. 62/681) was married to the Prophet after the death of her husband Abū Salama. Al-Ziriklī, A‘ tām, 3:97.

165 Abū Salama, b. 'Abd Allāh b. 'Umar b. Makhzūm (d. 3/624) an early convert who immigrated to Abyssinia, witnessed the battle of Badr, and died four months later. Al-Dhahabī, Siyar, 1:150.

166 Muslim, Șahīḥ, (hadìth no. 920), 2:634. 
dies, his eyes become fixedly open?" They replied: "Yes." He said, “That [happens] when his vision follows his soul." 167 [The Prophet] thus called it "spirit" one time and "soul" another.

Ahmad b. Hanbal and Ibn Māja narrated from Shaddād b. Aws ${ }^{168}$ that he said that the Messenger of God, may God bless him and grant him peace, remarked: "When you attend your dying ones, close the[ir] eyes because vision follows the spirit, and say [what is] good because [the angels] say 'Amen' upon what the people of the house have said." ${ }^{169} 170$ Proofs of this principle and the explanation of the meanings as well as the commonalities of the "spirit" and the "soul" are too many for this answer to accommodate. We have elaborated on them elsewhere. ${ }^{171}$

[Now,] it is clear through what we have mentioned that those who say that the spirits of Adamic beings are eternal and thus uncreated are among the major innovators [speaking of] God's indwelling (hulūl). Their statement leads to reductionism ( $\left.{ }^{\prime} a^{\prime} t \underline{i} l\right)$ by considering the slave as being the Lord and [to] other mendacious and misleading innovations.

As for the declaration of God Most High, "Say that the spirit (rūh) is from the command of my Lord," it was said that the spirit here is not the spirit of the Adamic being, but rather an angel [as mentioned] in [God's] statements: "The day when the Spirit and the angels will stand in a row,"[Q78:38] [227] "The angels and the Spirit will ascend to Him," ${ }^{[070: 4]}$ and "The angels and the Spirit descend therein by the permission of their Lord." ${ }^{[Q 97: 4]}$ It was also said: It is, rather, the spirit of the Adamic being. The two sayings are famous. Whether the verse indicates both of them or addresses only one of them, nothing in it proves that the spirit is uncreated, for two reasons.

First “command," [as used] in the Qur'ān, is sometimes meant as a verbal noun (mașdar) and other times as an object ( $m a f^{\prime} \bar{u} l$ ), namely, that which is commanded. For example, God Most High declares: "The Command of God has come up, so do not seek to hasten it"[Q16:1] and "The command of God is ever a destiny decreed."[Q33:38] This is also [true of] words other than "command," such as "creation," "power," "mercy," "speech," and so on. If the spirit were said to be part (ba'd) of

167 Ibid, (hadìth no. 921), 2:635.

168 Shaddād, b. Aws b. Thābit al-Khazrajī (d. Jerusalem, 85/677) a Companion who was installed by 'Umar b. al-Khaț̣āb in the emirate of Homs. See al-Ziriklī, al-A'lām, 3:158.

169 fa inna al-malā’ikata tu'amminu 'alā mā qãla ahlu l-bayt J: fa innahu yu'ammanu ālā mā yaqūlu ahlu 1-mayyit $\mathbf{F}$.

170 Ibn Māja, Sunan, (hadīth no. 1455), 1:468.

171 Mas'ala, MF, 9: 271-305; Shādhilī, 121-28; Dar', 10:292-98. 
God's command or an atom (juz') ${ }^{172}$ of God's command or something similar to that which explicitly [indicates] that it is part of God's command, then what is meant by the word "command" would be nothing but what is commanded, not the verbal noun. This is because the spirit is a self-subsisting entity; it goes and comes and is subject to bliss and torment. Now, it is inconceivable that this would be the verbal noun of "he commanded, he commands, a command." This is what the ancients of the community, its imāms and its majority, have said. Also, whoever among the Kalām theologians said that the spirit is an accident subsisting in the body did not mean that it was the verbal noun of "he commanded, he commands, a command."

When the Qur'ān is named "God's command," then it is the speech of God. Now, "speech" is the verbal noun of "he spoke, he speaks [to], in a certain manner, speech; and he spoke, in a certain manner, speech." Therefore, if [the Qur'ān] is named a "command" in the meaning of a verbal noun, this is congruous especially [because] speech is of two types: command and report.

[228] Self-subsisting entities are not named a "command" in the meaning of ${ }^{173}$ a verbal noun, but rather in the meaning of an object (i.e., that which is commanded). Thus the Messiah was called a "word" because he was created by the word. Likewise, the object of power is called "power," the Garden "mercy," and the rain "mercy" in, for instance, God's statement: "So observe the effects of the mercy of God: how He gives life back to the earth after its death." ${ }^{[Q 30: 50]}$ Similarly, the Prophet, God bless him and grant him peace, said, narrating from His Lord, that He told the Garden, "You are my mercy, by you I have mercy upon whom I will." ${ }^{174}$ The Prophet also said, "God created mercy-on the day He created it-as one hundred mercies." 175 There are many [other examples] like these.

Here is the response of Abū Sa'īd al-Kharrāz:

If it is said that God Most High ordered: "Say that the spirit is from the command of my Lord" and that God's command is from Him, then it shall be answered that the command of God Most High is what is commanded and brought into being by the agency of the One Who brought it into being. 
Ibn Qutayba spoke likewise in [his] Kitāb al-Mushkil ${ }^{176}$ and remarked that the categories of the spirit [are the following]:

[The spirit] is the spirit of the bodies that God takes at death. The spirit is also Gabriel. God Most High proclaimed: "The Trustworthy Spirit has brought it down"[026:193] and "We supported him with the Holy Spirit,"[Q2:87] namely, Gabriel. Also the spirit, according to the commentators, is a great angel from among the angels of God Most High, who will stand alone forming one row, whereas the [rest of] angels will stand [in] one row. God Most High also declared: "And they ask you about the spirit. Say: "The spirit is from the command of my Lord." He said that the spirit is related to God because it is by His command or because it is by His word. ${ }^{177}$

Second, the preposition "from" in the [Arabic] language might indicate the genus, as in "a door [made] from [i.e., of] iron." It might also [indicate] the starting point of something, as in "I departed from Makkah." Therefore, the statement of God Most High that "The spirit is from the command of my Lord" does not signify that the spirit is part of the command or of [229] its genus. Rather, it might indicate the starting point, if [the spirit] were brought into being by [God's] command and originated from it. This is the meaning of Imām Aḥmad's answer about God's saying "and a spirit from Him."[Q4:171] He said:

As for God's saying "a spirit from Him," He announces that by His command the spirit was from Him, just as He says, "He has made of service to you whatever is in the skies and whatever is on Earth; everything being from Him." ${ }^{[Q 45: 11]}$ He means "from His command," and the explanation of "the Spirit of God" [only carries the meaning] that it is a spirit by the word of God, which God created, as it is said "servant of God" and "sky of God."[Q4:220]

Also similar to this is His declaration: "And whatever you have of favor, it is from God." [16:52] Since the things subjected [to humanity] and blessings are from God are not parts of His essence, but rather things that originated from Him, God's identification of the Messiah as "a spirit from Him" does not necessarily mean that he is part of God's essence. It is also known that this specific phrase is more rhetorical than "the spirit is from the command of my Lord." Since the first phrase

176 Ibn Qutayba, Ta’wīl mushkil al-Qur'ān, ed. Sayyed Aḥmad Șaqr (Cairo: Maktabat Dār al-Turāth, 1393/1973), 485-86.

177 Ibn Qutayba: “The Messiah is the spirit of God, because Gabriel breathed him into Mary's chemise. The spirit is related to God, because it came into being by His command. God proclaimed: 'So We breathed into her of Our Spirit' [Q21:91], which means Gabriel's breath. [The Messiah] was called the spirit of God because he came into being by God's word. God Most High said, 'Be,' so he came into being" (Ta'will mushkil al-Qur'ān, 487). 
neither excludes that [Jesus] is created, nor necessarily entails that he is part of [God], God's saying the "the spirit is from the command of my Lord," a fortiori, neither excludes that [this spirit] is created nor necessarily entails that it is part of God or of His command. This prevails, if "command" is that command that is one of the attributes of God.

Each of these two answers is independent. It is, however, possible to derive a composite answer from both of them. It would then be said that [in] God's saying "the spirit is from the command of my Lord," the "command" means either what is commanded or is an attribute of God Most High. If the former is meant, then it would be possible that the spirit is part of that [command] and would thus be created. If by the "command" is meant an attribute of God, then His saying "the spirit is from the command of my Lord" would be like His saying "and a spirit from Him" and His saying "everything being from Him" and so on.

Such confusion only arose when it was thought that the command is an eternal attribute of God and that the spirit of [230] the children of Adam is part of this attribute. The verse does not, however, indicate either of these two premises. God Exalted knows better.

The word "spirit" occurs in the Qur'ān with still another meaning, such as God's saying, "And thus We have revealed to you an inspiration from Our command,"[Q42:52] "He has decreed within their hearts faith and [has] supported them with a spirit from Him," ${ }^{[058: 22]}$ and the like. The Qur'ān that God sent down is God's speech. However, speaking about this is not related to [the answer of] this question.

As for the asker's asking, "Is what is entrusted to God Most High a matter of its essence, its attributes, or both together?" this is not among the things to be said, especially about the spirit. It is not even permissible for anyone to pursue what he has no knowledge of, nor to say about God what he does not know. God Most High announced: "And do not pursue that of which you have no knowledge. Indeed, the hearing, the vision and the heart-about all those [one] will be questioned." [Q17:36] God Most High also proclaimed: "Say: 'My Lord has indeed forbidden abominations - what is apparent of them and what is concealed - sin, oppression without right, that you associate with God that for which He has not sent down authority, and that you say about God that which you do not know." [Q7:33] God Most High further said: "Was not the covenant of the Scripture taken from them that they would not say about God except the truth?"[Q7:162] When God told the angels: "Inform Me of the names of these, if you are truthful,"[Q2:31] they replied: "Exalted are You; we have no knowledge except what You have taught us. Indeed, it is You 
who is the Knowing, the Wise." ${ }^{[\mathrm{Q} 2: 32]}$ Also, Moses asked al-Khadir ${ }^{178}$ : "May I follow you on [the condition] that you teach me from what you have been taught of right guidance?"[Q18:66] Al-Khadir replied, after seeing a sparrow dip its beak into the sea: "My knowledge and your knowledge have not taken away from God's knowledge, ${ }^{179}$ except as what this sparrow has taken away from this sea." 180

[231] Neither the Book nor the Sunna forbid Muslims to speak about the spirit in terms of what both of them indicate of its essence and attributes. Speaking without knowledge is prohibited in everything. However, it is established in the two Șahịhs on the authority of Ibn Ma'sūd that the Prophet, God bless him and grant him peace, was once in one of the streets of al-Madina and some of them [i.e., the Jews] remarked: "Ask him about the spirit" and others warned them: "Do not ask him, lest he should tell you something that you [will] hate." [Ibn Ma'sūd] said that they asked him while he was leaning against a palm-leaf stalk. Consequently, God sent down this verse. ${ }^{181}$

God has thereby made it clear that the kingdom of the Lord is great, as are His soldiers. Their description and His power are too great to be encompassed by the Adamic beings. They were indeed given only a little knowledge. Therefore, let whoever claims to have knowledge not think that he can know everything about which he is asked and all that is in existence, because "no one knows the soldiers of your Lord except He."[Q74:31]

\section{Bibliography}

Abrahamov, Binyamin. Ibn al-'Arabi and the Sufis. Oxford: Anqa Publishing, 2014.

Adamson, Peter. “Correcting Plotinus: Soul's Relationship to Body in Avicenna's Commentary on The Theology Of Aristotle." Bulletin of the Institute of Classical Studies 47 (2004): 59-75.

Addas, Claude. Ibn 'Arabi: The Voyage of no Return. Translated by David Streight. Cambridge: The Islamic Texts Society, 2000 [repr. 2010].

Ahmed, Shahab. "Ibn Taymiyyah and the Satanic Verses." Studia Islamica 87.2 (1998): 67-124. al-1.) [EIR].

Allison, Christine. "Yazidis." In Encyclopæedia Iranica (http://www.iranicaonline.org/articles/yazidis-i-gener-

al-Andalusī, Ibn 'Ațiyya (d. 542/1147). al-Muharrar al-wajīz fì tafsīr al-Kitāb al-'Azīz. Edited by 'Abd al-Salām 'Abd al-Shāfī, 5 vols. Beirut: Dār al-Kutub al-'Ilmiyya, 1422/2001.

179 On whether God's knowledge is susceptible to decrease, see al-Nawawī (d. 676/1277), Șahīh Muslim bi-sharh al-Nawawi (Cairo: al-Mațba'at al-Mișriyya, 1349/1930), 8:141; Ibn Hajar (d. 852/1449), Fath al-bārī bi-sharḥ saḥịh al-Bukhārī, ed. Muhị al-Dīn al-Khațîb, 13 vols. (Cairo: al-Maktaba al-Salafiyya, 1380/1960), 1:220.

180 Al-Bukhārī, Șaḥị̣, (ḥadīth no. 3401), 4:154; Muslim, Șaḥịh, (ḥadìth no. 2380), 4:1874.

181 Al-Bukhārī, Șaḥìh, (ḥadīth no. 4721), 6:87; Muslim, Șaḥịh, (hadìth no. 2794), 6:2152. 
AlSharhan, Saud. "Early Muslim Traditionalism: A Critical Study of the Works and Political Theology of Ahmad Ibn Hanbal.” PhD diss., University of Exeter, 2011.

Arberry, A. J. “al-Djunayd." In $E I^{2}$.

al-'Asqalānī, Ibn Ḥajar (d. 852/1449). Fatḥ al-Bārī bi-sharḥ saḥịh al-Bukhārī. Edited by Muhị al-Dīn al-Khațīb, 13 vols. Cairo: al-Maktaba al-Salafiyya, 1380/1960.

al-Baghdādī, Al-Khațīb (d. 463/1072). Tãrīkh Baghdād. Edited by Bashshār Ma'rūf, 16 vols. Beirut: Dār alGharb al-Islāmī, 1422/2002.

al-Baghdādī, Ismāīil (d. 1339/1920). Hadiyyat al-ârifin asmä’ al-mu'allifín wa āthār al-mușannifin, 2 vols. Istanbul: Wakālat al-Ma‘ārif al-Jalīla, 1951.

al-Bukhārī, Muhammad b. Ismāîil (d. 256/870). al-Jāmi al-Ṣaḥịh, 9 vols. Cairo: Būlāq, 1311/1893.

Calverley, E. E. and I. R. Netton. "Nasf." In $E I^{2}$.

Cook, Michael. Commanding Right and Forbidding Wrong in Islamic Thought. Cambridge: Cambridge University Press, 2004.

Cooke, Francis T. “Ibn al-Qaiyim's Kitāb al-Rūḥ: Translation with Introduction and Annotation." PhD diss., Hartford Seminary Foundation, 1934. “Ibn al-Qaiyim's Kitāb al-rūḥ.” The Muslim World 25 (1935): 129-144.

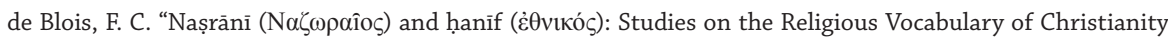
and of Islam." Bulletin of the School of Oriental and African Studies 65.1 (2002): 1-17.

al-Dhahabī, Shams al-Dīn (d. 748/1347). Siyar a'lām al-nubalā'. Edited by Shu'ayb al-Arnā'ūț et al. 25 vols. Damascus: Mu'assasat al-Risāla, 1405/1985.

Tārīkh al-islām wa wafayāt al-mashāhīr wa l-åām. Edited by Bashshār Ma'rūf, 17 vols. Beirut: Dār alGharb al-Islāmī, 1423/2003.

al Fārūqī, Ismā'îl Rājì. Islam: Religion, Practice, Culture \& World Order. Edited by Imtiyaz Yusuf. London and Washington: The International Institute of Islamic Thought, 2012.

El Omari, Racha. "Ibn Taymiyya's 'Theology of the Sunna' and his Polemics with the Ash'arites." In Ibn Taymiyya and His Times, ed. Yossef Rapoport and Shahab Ahmed, 101-19. Karachi: Oxford University Press, 2010.

Fiey, Q. M. "Nașārā." In $E I^{2}$.

Gardet, L. "Kalām." In $E I^{2}$.

al-Ghazālī, Abū Ḥāmid (d. 555/1111). Nafkh al-rūḥ wa l-taswiya. Edited by Aḥmad Hijāzī al-Saqqā. Cairo: Mațba'at Dār al-Bayān, 1399/1979.

. The Incoherence of the Philosophers=Tahăfut al-falāsifa. Translated by Michael E. Marmura. Utah: Brigham Young University Press, 2000.

Griffel, Frank. "Al-Ghazālī’s Unspeakable Doctrine of the Soul: Unveiling the Esoteric Psychology and Eschatology of the Ihyā’’ by Timothy J. Gianotti.” Journal of the American Oriental Society 124.1 (2004): 107-11.

-_- Al-Ghazālī's Philosophical Theology. New York: Oxford University Press, 2009.

Gutas, Dimitri. “Avicenna: The Metaphysics of the Rational Soul.” The Muslim World 102.3-4 (2012): 417-25.

al-Hakkārī, 'Adī b. Musāfir (d. 557/1162). I'tiquad ahl al-sunna wa l-jamā'a. Edited by Ḥamdī al-Salafĩ and Taḥsīn al-Dūsakì. Al-Madina: Maktabat al-Ghurabā’ al-Athariyya, 1419/1998.

Hallaq, Wael. Ibn Taymiyya Against the Greek Logicians. New York: Oxford University Press, 1993.

al-Hanbalī, Ibn Rajab (d.795/1392 or 1393). Fatḥ al-Bārī sharḥ șahīḥ al-Bukhārī. Edited by Mahmūud 'Abd al-Maqșūd et al. 10 vols. Al-Madīna: Maktabat al-Ghurabā’ al-Athariyya, 1416/1996.

Hermansen, Marcia. "Eschatology." In The Cambridge Companion to Classical Islamic Theology, ed. Tim Winter, 308-24. New York: Cambridge University Press, 2008.

Ḥilmī, Mușțafā. Ibn Taymiyya wa-l tașawwuf. Alexandria: Dār al-Da'wa, 1982.

. Introduction to Henri Laoust, Nazariyyāt Shaykh al-Islām Ibn Taymiyya fi l-siyāsa wa l-ijtimā'=Essai sur les doctrines sociales et politiques de Takì-d-Dīn Ahmad b. Taimīyah. Translated by Muhammad 'Abd al-'Azịim 'Alī, 2 vols, 1:7-119. Cairo: Dār al-Anșār, 1396/1976. 
Holtzman, Livnat. "Human Choice, Divine Guidance and the Fițra Tradition: The Use of Hadith in Theological Treatises by Ibn Taymiyya and Ibn Qayyim al-Jawziyya." In Ibn Taymiyya and His Times, ed. Yossef Rapoport and Shahab Ahmed, 163-88. Karachi: Oxford University Press, 2010.

Homerin, Th. E. “Ibn Taimīya's al-Ṣūfiyah wa-al-Fuqarä'.” Arabica 32, (1985): 219-44.

Hoover, Jon. "Fițra." In $E I^{3}$.

"Hanbali Theology." In The Oxford Handbook of Islamic Theology, ed. Sabine Schmidtke (2014). Accessed on June 10, 2015, DOI: 10.1093/oxfordhb/9780199696703.013.014.

"Perpetual Creativity in the Perfection of God: Ibn Taymiyya's Hadith Commentary on God's Creation of this World." Journal of Islamic Studies 15.3 (2004): 287-329.

Theodicy of Perpetual Optimism. Leiden: Brill, 2007.

Ibn al-Hajjāj, Muslim (d. 261/874). Șaḥihh Muslim. Edited by Muḥammad F. 'Abd al-Bāqī, 5 vols. Cairo: Dār Ihyyā’ al-Kubub al-'Arabiyya. Repr., Dār al-Hadìth, 1412/1991.

Ibn al-Jawzī, Abū l-Faraj (d. 587/1201). Daf' shubah al-tashbīh bi-akuff al-tanzīh. Edited by Ḥasan al-Saqqāf. Beirut: Dār al-Imām al-Rawwās, 1428/2007. Turāth, n.d.

. Daf' shubhat al-tashbīh. Edited by Muhammad Zāhid al-Kawtharī. Cairo: al-Maktaba al-Azhariyya li-

The Attributes of God: Ibn al-Jawzī's Daf' Shubah al-Tashbīh bi-Akaff (sic) al-Tanzīh. Translated by 'Abd Allāh bin Ḥāmid 'Alī and forwarded by Khalid Blankinship. Bristol: Amal Press, 2006.

Ibn al-Mubārak, 'Abd Allāh (d. 181/797). al-Zuhd wa l-raqā’iq. Edited by Habīb al-Rahmān al-A'żamī. Beirut: Dār al-Kutub al-'Ilmiyya, 1400/1980.

Ibn Ḥanbal, Ahmad (d. 241/855). al-Musnad. Edited by Shu'ayb al-Arnā'ūṭ et al., 50 vols. Damascus: Mu'ssasat al-Risāla, 1422/2001.

al-Radd 'alā al-zanādiqa wa l-jahmiyya fïmā shakkū fỉhī min mutashābih al-Qur'ān wa ta'wwalūhū 'alā ghayri ta'wīlih. Edited by Daghash al-'Ajamī. Kuwait: Ghirās, 1426/2005.

al-Radd 'alā al-jahmiyya wa l-zanādiqa fìmā shakkū fỉhī min mutashābih al-Qur'ān wa ta'wwalūhū 'alā ghayri ta'wīlih. Edited by Șabrī Shāhīn. Riyadh: Dār al-Thabāt, 1424/2003.

al-Zuhd. Edited by Muhammad Shāhīn. Beirut: Dār al-Kubub al-'Ilmiyya, 1420/1999.

Ibn Kathīr, Abū l-Fidā' (d. 774/1372). Jāmi' al-masānīd wa l-sunnan al-hādī li-aqwam sanan. Edited by 'Abd al-Malik al-Deheish, 12 vols. Beirut: Dār Khiḍr, 1419/1998.

Ibn Māja, Muhammad b. Yazīd (d. 273/887). al-Sunan. Edited by Muhammad F. 'Abd al-Bāqī, 2 vols. Cairo: Dār Ihyyā' al-Kutub al-'Arabiyya, n.d.

Ibn Manda, Abū 'Abd Allāh (d. 395/1005). Kitāb al-tawhìd wa-ma'rifat asmä' Allāh wa-șifātih 'alā l-ittifāq wa l-tafarrud. Edited by ‘Alī al-Faqīhī, 3 vols. Al-Madīna: Mațābi‘ al-Jāmi‘a al-Islāmiyya, 1413/1992.

Ibn Qutayba, Abū Muhammad (d. 276/889). al-Ikhtiläffì l-lafž wa l-radd 'alā l-jahmiyya wa l-mushabbiha. Edited by ‘Umar Mahmūud Abū ‘Umar. Riyadh: Dār al-Rāya, 1412/1991.

Ta’wīl mushkil al-Qur'ān. Edited by Sayyed Aḥmad Ṣaqr. Cairo: Maktabat Dār al-Turāth, 1393/1973.

Ibn Taymiyya (d. 728/1328). See the "Primary Sources of the Study" section in the Introduction above..

al-Jawziyya, Ibn Qayyim (d. 751/1350). Kitāb al-rūḥ. Edited by Muhammad Ajmal al-Iṣlāhīi. 2 vols. Mecca: Dār ‘Ālam al-Fawā'id, 1432/2011.

Karamustafa, Ahmet. “Antinomian Sufis.” In The Cambridge Companion to Sufism, ed. Lloyd Ridgeon, 101-24. New York: Cambridge University Press, 2015.

al-Kharrāz, Abū Sałîd (d. 286/899). Kitāb al-șiḍ. Edited by A. J. Arberry. London, New York, Bombay, Calcutta, and Madras: Oxford University Press, 1937.

Kazi, Yasir. "Reconciling Reason and Revelation in the Writings of Ibn Taymiyya (d. 728/1328): An Analytical Study of Ibn Taymiyya’s Dar' al-ta'āruḍ.” PhD diss., Yale University, 2013.

Knysh, Alexander, trans. Al-Qushayrî's Epistle on Sufism=Al-Risala al-qushayriyya fi 'Ilm al-tasawwuf. Reading, UK: Garnet Publishing Ltd., 2007. 
_-_. Ibn 'Arabi in the Later Islamic Tradition. Albany: State University of New York, 1999.

Krawietz, Birgit. “Ibn Qayyim al-Jawzīyah: His Life and Works.” Mamlūk Studies Review 10 (2006): 19-64.

Kreyenbroek, P. G. “Yazīdī.” In $E I^{2}$.

Kukkonen, Taneli. "Receptive to Reality: Al-Ghazāli on the Structure of the Soul." The Muslim World 102.3-4 (2012): 541-61.

Langermann, Tzvi. "Ibn al-Qayyim's Kitāb al-rūḥ: Some Literary Aspects.” In Islamic Theology, Philosophy and Law: Debating Ibn Taymiyya and Ibn Qayyim al-Jawziyya. Edited by Birgit Krawietz and Georges Tamer, 94-122. Berlin: de Gruyter, 2012. (2010): 201-218.

. "The Naturalization of Science in Ibn Qayyim Al-Ğawziyyah's Kitāb al-rūḥ." Oriente Moderno, XC

Laoust, Henri. “Ạ̣mad b. Hanbal." In $E I^{2}$.

———. "Hanābila." In $E I^{2}$.

-_—. "Ibn al-Djawzī." In $E I^{2}$.

- ——. "Ibn al-Farrā'." In $E I^{2}$.

Lecomte, G. “Ibn Kutayba.” In $E I^{2}$.

Macdonald, Duncan B. “The Development of the Idea of Spirit in Islam I." The Muslim World 22.1 (January 1932), 25-42 [part II: 153-68, April 1932]; reprinted from idem, Acta Orientalia 9 (1931), 307-51.

Madelung, Wilferd. "al-Kharrāz." In $E I^{2}$. . "al-Kharrāz." In $E I^{2}$.

—_—. "Ibn al-Malāḥimī on the Human Soul.” The Muslim World 102.3-4 (2012): 426-32.

Makdisi, George. "Ibn Taymiyya: A Sufi of the Qadiriya Order." American Journal of Arabic Studies 1 (1973): 118-29. “Ibn 'Akịil.” In $E I^{2}$.

Martin, Richard. “Createdness of the Qur'ān.” In Encyclopaedia of the Qur'ān. Edited by Jane Dammen McAuliffe, 1: 467-71. Brill: Leiden-Boston-Köln, 2001.

Mason, Herbert. Al-Hallaj. London and New York: Routledge, 1995.

Massignon, L. and G. Anawati. "al-Ḥallāj.” In $E I^{2}$.

——. "Hulūl." In $E I^{2}$. sity Press, 1994

. Hallaj: Mystic and Martyr. Translated and abridged by Herbert Mason. New Jersey: Princeton Univer-

Al-Matroudi, A. I. The Hanbali School of Law and Ibn Taymiyyah: Conflict or Conciliation. London: Routledge, 2006.

Memon, Muhammad. Ibn Taimìya's Struggle against Popular Religion. Paris and The Hague: Mouton, 1976.

Michel, Thomas. A Muslim Theologian's Response to Christianity: Ibn Taymiyya's Al-Jawab Al-Sahih. New York: Caravan Books, 1984.

Michot, Yahya. "Ibn Taymiyya's Commentary on the Creed of al-Hallāj." In Sufism and Theology. Edited by Ayman Shihadeh, 123-36. Edinburgh: Edinburgh University Press, 2007.

—_—. "Revelation." In The Cambridge Companion to Classical Islamic Theology. Edited by Tim Winter, 18-96. New York: Cambridge University Press, 2008.

_-_. Ibn Taymiyya against Extremisms. Paris: Albouraq, 2012.

Mirenayat, S. A. and E. Soofastaei. "Gerard Genette and the Categorization of Textual Transcendence." Mediterranean Journal of Social Sciences 6.5 (2015): 533-37.

Monnot, G. "Sumanis," In $E I^{2}$.

al-Nawawī, Yahyyā b. Sharaf (d. 676/1277). Șaḥih Muslim bi-sharḥ al-Nawawī, 18 vols. Cairo: al-Mațba'at al-Mișriyya, 1347-49/1929-30. 
Özervarli, M. S. "Divine Wisdom, Human Agency and the fițra in Ibn Taymiyya's Thought." In Islamic Theology, Philosophy and Law: Debating Ibn Taymiyya and Ibn Qayyim al-Jawziyya. Edited by Birgit Krawietz and Georges Tamer, 78-100. Berlin: de Gruyter, 2012.

Pellat, C. "Fatra." In $E I^{2}$.

al-Qārī, 'Alī Mullā (d. 1014/ 1606). Mirqāt al-mafātīh sharḥ mishkāt al-mașābīh. Edited by Ṣidqī al-'Aț̣āār, 11 vols. Beirut: Dār al-Fikr, 1414/1994.

al-Rāzī, Fakhr al-Dīn (d. 606/1210). Mafātīh al-ghayb=al-Tafșir al-kabìr, 32 vols. Beirut: Dār al-Fikr, 1401/1981.

Rentz, G. "Barhūt." In $E I^{2}$.

Robson, J. “Abū Hurayra." In $E I^{2}$.

Rosenthal, Franz. "Ebn Qotayba, Marwazī Mohammad 'Abd al-Allāh.” in EIR.

Sezgin, Fuat. Geschichte des arabischen Schrifttums, 1-8 vols. Leiden: E. J. Brill, 1967-1984; 9-13 vols. Frankfurt am Main: Wolfgang Goethe-Universität 2000-2007.

al-Sarrāj, Abū Nașr (d. 378/988). Kitāb al-luma'. Edited by 'Abd al-Ḥalīm Maḥmūd and Ṭāhā 'Abd al-Bāqī Surūr. Cairo: Dār al-Kutub al-Ḥadītha and Baghdad: Maktabat al-Muthannā, 1380/1960.

Shihadeh, Ayman, ed. "The Ontology of the Soul in Medieval Arabic Thought." The Muslim World, 102.3-4 (2012): 413-616.

al-Tha'labī, Abū Isḥāq (d. 427/1035). al-Kashf wa-l bayān 'an tafsīr al-Qur'ān. Edited by Abū Muhammad b. 'Āshūr and Nazịir al-Sā‘idī, 10 vols. Beirut: Dār Iḥyā’ al-Turāth al-'Arabī, 1422/2002.

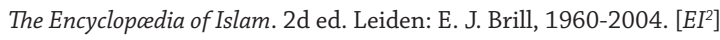

Vaglieri, L. V. “'Abd Allāh b. al-'Abbās.” In $E I^{2}$.

van Ess, Joseph. “Tashbīh wa-Tanzīh.” In $E I^{2}$. Press, 2006.

al-Wāhịidī, Abu-l Ḥasan (d. 468/1076). al-Wajīz fì tafsīr al-Kitā al-'Azīz. Edited by Ṣafwān A. Dāwūdī. Beirut: Dār al-Qalam and Damascus: al-Dār al-Shāmiyya, 1415/1994.

Watt, W. M. “Djahm b. Ṣafwān.” In $E I^{2}$.

"Djahmiyya." In $E I^{2}$.

Wensinck, A. "al-Khadir." In $E I^{2}$.

al-Ziriklī, Khayr al-Dīn (d. 1396/1976). al-A'ām, 8 vols. Beirut: Dār al-'Ilm lil-Malāyīn, 2002. 